\title{
Three new species of Pruvotinidae (Mollusca: Solenogastres) from Antarctica and NW Spain
}

\author{
Maria Zamarro • Oscar García-Álvarez • \\ Victoriano Urgorri
}

Received: 23 July 2010/Revised: 6 August 2012/ Accepted: 28 September 2012/Published online: 20 October 2012

(C) Springer-Verlag Berlin Heidelberg and AWI 2012

\begin{abstract}
The family Pruvotinidae (Solenogastres, Cavibelonia) includes thirty species of fifteen genera grouped in five subfamilies. These subfamilies are defined by the combination of the presence or absence of hollow hookshaped sclerites, the presence or absence of a dorsopharyngeal gland and the type of ventrolateral foregut glandular organs: type A, type $\mathrm{C}$ or circumpharyngeal. In this paper, three new species of the family Pruvotinidae are described: Pruvotina artabra n. sp. and Gephyroherpia impar n. sp. from NW Spain, and Pruvotina manifesta n. sp. from Antarctic Peninsula. These new descriptions increase the global knowledge of Solenogastres biodiversity.
\end{abstract}

Keywords Mollusca - Solenogastres - Pruvotinidae · Pruvotina $\cdot$ Gephyroherpia $\cdot$ New species

\section{Introduction}

The Solenogastres are a small class of shell-less vermiform Mollusca with calcareous sclerites, a ventral pedal groove

Communicated by Peter Funch.

M. Zamarro ( $\square)$

Instituto de Acuicultura, Universidade de Santiago de

Compostela, 15782 Santiago de Compostela, Spain

e-mail: maria.zamarro@usc.es

O. García-Álvarez · V. Urgorri

Departamento de Zooloxía e Antropoloxía Física,

Facultade de Bioloxía, Universidade de Santiago de Compostela,

15782 Santiago de Compostela, Spain

V. Urgorri

Estación de Bioloxía Mariña da Graña, Universidade de Santiago de Compostela, A Graña, 15590 Ferrol, Spain and a terminal or subterminal pallial cavity. They are a common, and sometimes abundant, part of the benthic biotypes, inhabiting marine bottoms from depths of $1-6,850 \mathrm{~m}$ (predominantly below $50 \mathrm{~m}$ ), and they are carnivorous, feeding chiefly on Cnidaria. The class Solenogastres includes about 260 species, grouped into 23 families within 4 orders.

The ventrolateral foregut glandular organs are present in most taxa of Solenogastres and their variable configuration means an important suprageneric taxonomic character (Salvini-Plawen 1978; Handl and Todt 2005; GarcíaÁlvarez and Salvini-Plawen 2007); moreover, many species show unicellular pharyngeal glands. However, the dorsopharyngeal gland is restricted to a number of taxa as some genera within the family Pruvotinidae Heath, 1911 (García-Álvarez and Salvini-Plawen 2007) and some species of Nematomenia Simroth, 1893 and Proneomenia Hubrecht, 1880 (Pruvot 1890, 1891; Thiele 1902; Heath 1911, 1918; Salvini-Plawen 1978; García-Álvarez et al. 2009). The dorsopharyngeal gland is a multi-cellular structure that consists of a dense package of subepithelial glandular cells limited to the dorsal region of the preradular pharynx, which open either directly into the lumen of the pharynx or into a dorsal pharyngeal pouch (papilla) (Handl and Todt 2005; García-Álvarez and Salvini-Plawen 2007; Gil-Mansilla et al. 2011).

Fifteen of the thirty species of the family Pruvotinidae are known for Antarctic and sub-Antarctic waters; the genus Pruvotina Cockerell, 1903, was represented by 9 species in this area before the present work. This can be extended to the global of Solenogastres, in which almost $50 \%$ of the species have been described for the Antarctic and sub-Antarctic regions. In the European Atlantic, five species and an innominate species of the family Pruvotinidae were known: Eleutheromenia sierra (Pruvot, 1890) 
from Costa Brava, Roscoff (France), Irish Sea and Trondheim (Norway); Gephyroherpia (?) triangulata Salvini-Plawen, 2009 and Eleutheromenia sp. from the Irish Sea; and Pararrhopalia pruvoti Simroth, 1893, Luitfriedia minuta García-Álvarez and Urgorri, 2001 and Unciherpia hirsuta García-Álvarez, Salvini-Plawen and Urgorri, 2001 from the coast of Galicia (NW Spain) (Pruvot 1897; García-Álvarez and Urgorri 2001; García-Álvarez et al. 2001; Salvini-Plawen 1997, 2003, 2008a, 2009; Todt 2006; García-Álvarez and Salvini-Plawen 2007).

The efforts made in the study of the European sea bottoms during the last decades have significantly increased the records of Solenogastres (see Salvini-Plawen 1997; García-Álvarez and Salvini-Plawen 2007). Nevertheless, the continuous appearance of new species, as shown in this communication, indicates that Solenogastres biodiversity has been underestimated, even in the areas where previous research work has been done.

\section{Materials and methods}

The specimens studied were collected in the expeditions DIVA-Artabria I/2002 and 2003 in NW Galicia (NW Spain) and in the Antarctic expedition BeNTART-2006.

Specimens were fixed and preserved in $70 \%$ ethanol. Animals were photographed and measured, and the external anatomy was described. Sclerites were studied directly on the animal and by separating small pieces of the mantle from the dorsal and lateral areas of the body. These pieces were treated with $5 \%$ sodium hypochlorite for $12 \mathrm{~h}$ in order to isolate the sclerites; they were later rinsed with water, dried in a heater at $40{ }^{\circ} \mathrm{C}$ and mounted using Eukitt or Araldite for examination by light microscopy or shadowed with gold-palladium for study under scanning electron microscope (SEM). For their anatomical study, specimens were decalcified in an EDTA solution for $12 \mathrm{~h}$, and then dehydrated and embedded in paraffin or araldite: The paraffin blocks were cut in $5-\mu \mathrm{m}$ transverse sections and stained with Mallory's trichromic; the araldite blocks were cut in ribbons of semithin serial sections (ca. $2 \mu \mathrm{m}$ ) with glass knives and stained with Richardson's blue. Histological examination and reconstruction were done under Olympus microscope.

Systematic descriptions

Order Cavibelonia Salvini-Plawen, 1978

Family Pruvotinidae Heath, 1911

Synonyms Parameniidae Simroth, 1893; Paramenidae Pruvot, 1902; Perimeniidae Nierstrasz, 1908 (part); Pruvotiniidae Heath, 1911; Pararrhopaliidae Salvini-Plawen, 1972.
With hollow acicular sclerites; with or without hollow hook-shaped sclerites. Radula distichous or missing. With or without dorsopharyngeal gland. Ventrolateral foregut glandular organs of ducts with subepithelially/extraepithelially arranged gland cells, or circumpharyngeal subepithelial/extraepithelial follicular glands, or with epithelial/intraepithelial gland cells. With or without respiratory organs.

Subfamily Pararrhopaliinae Salvini-Plawen, 1978

With hollow hook-shaped sclerites. Ventrolateral foregut glandular organs of ducts with subepithelially/extraepithelially arranged gland cells. With a dorsopharyngeal papilla gland.

Genus Pruvotina Cockerell, 1903

Synonyms Paramenia Pruvot, 1890 (part.) (non Brauer and Bergenstamm, 1889); Perimenia Nierstrasz, 1908 (part.).

Distichous radula present. Midgut with regular constrictions. Secondary genital opening unpaired. Without copulatory stylets. With dorsoterminal sense organ. With respiratory organs.

TyPe SPECIES Paramenia impexa Pruvot, 1890.

Pruvotina artabra n. sp. (Figs. 1, 2, 3, 4)

\section{Type material}

Mature holotype and paratypes 1-3 (mature) and 7-10 (immature) cut in $5 \mu \mathrm{m}$ serial sections. Paratype 4 (mature) cut in $2 \mu \mathrm{m}$ serial sections. Paratypes 5-6 preserved in $70^{\circ}$ ethanol.

The holotype (MHN USC 1008) and paratype 5 (MHN USC 10009) are deposited in the Museo de Historia Natural of the University of Santiago de Compostela. Paratypes 1-4 and 6-10 are part of the collection of the Zoology and P. A. Department at the University of Santiago de Compostela.

\section{Type locality}

NW Galicia (NW Spain). Expedition DIVA-ARTABRIA I/2002. Station DIVA-ARTABRIA I/2002 AT-1000 $\left(43^{\circ} 57.03^{\prime} \mathrm{N}\right.$; $\left.08^{\circ} 54.795^{\prime} \mathrm{W}-43^{\circ} 57.248^{\prime} \mathrm{N} ; 08^{\circ} 54,133^{\prime} \mathrm{W}\right), 1,132-1,191 \mathrm{~m}$ depth; holotype and paratypes 1-6.

\section{Other localities}

NW Galicia (NW Spain). Expedition DIVA-ArtabriA I/2003. Station DIVA-ARTABRIA I/2003 AT-1000 (4353, $\left.847^{\prime} \mathrm{N}-08^{\circ} 57,324^{\prime} \mathrm{W} ; 43^{\circ} 54,621^{\prime} \mathrm{N}-08^{\circ} 57,361^{\prime} \mathrm{W}\right), 993-$ $1,004 \mathrm{~m}$ depth: paratype 7. Station DIVA-ARTABria I/2003 


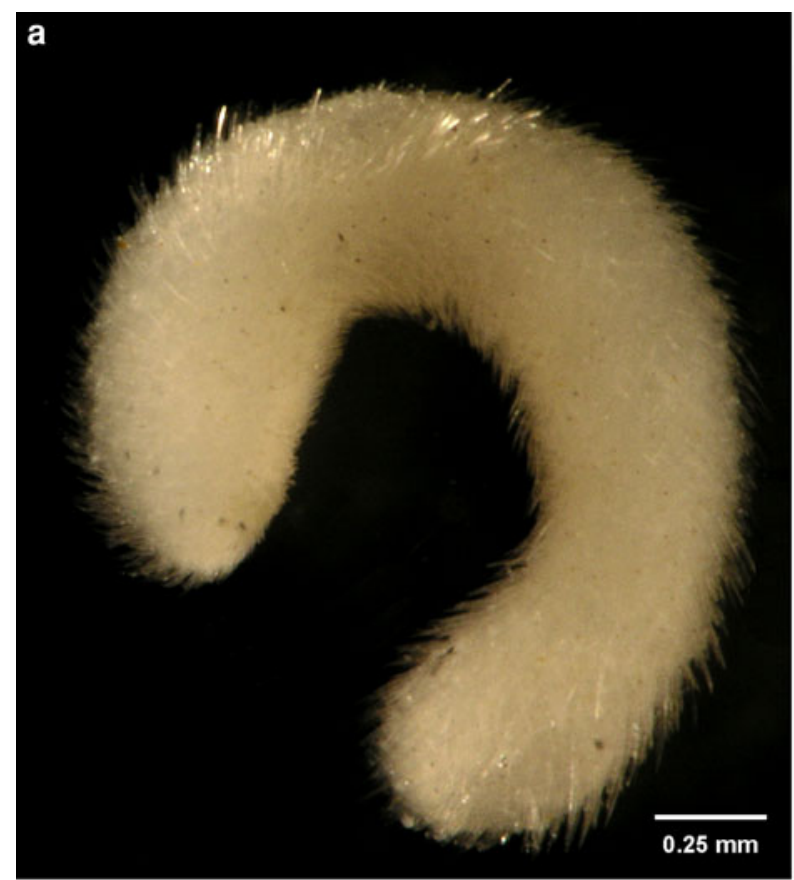

C
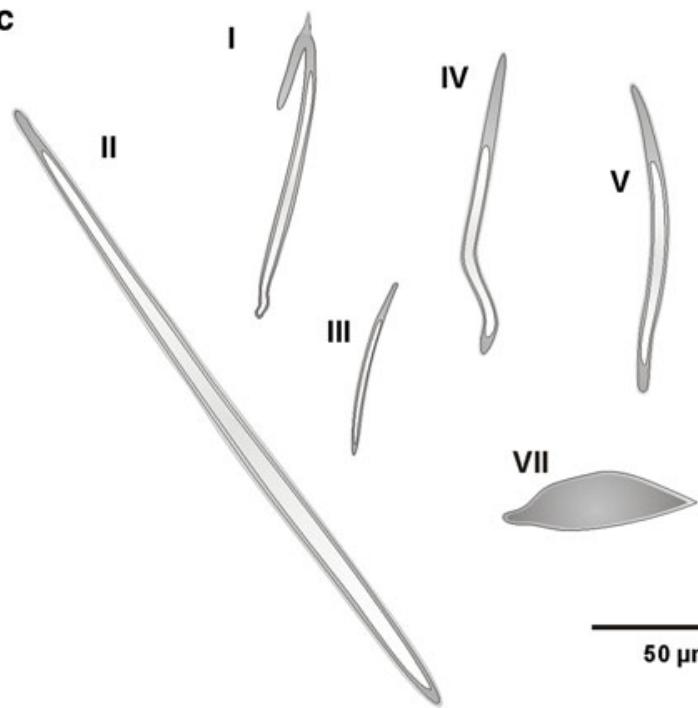

$50 \mu \mathrm{m}$

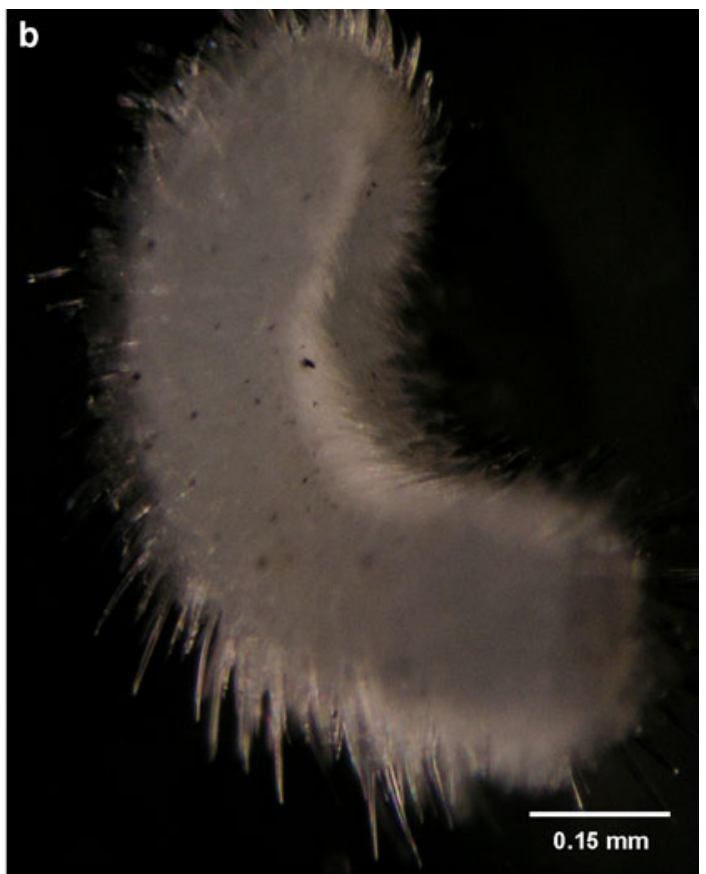

d
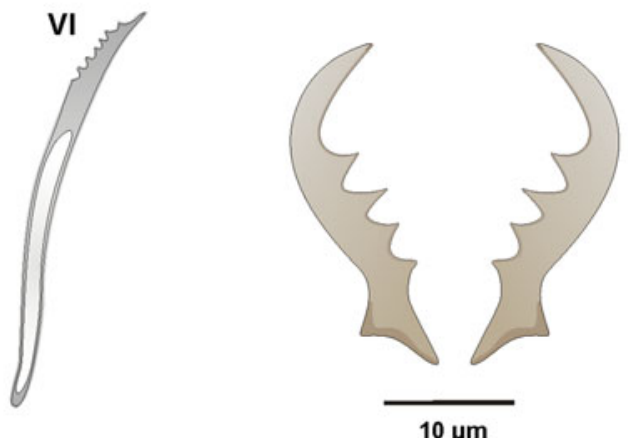

Fig. 1 Pruvotina artabra n. sp. a-b habitus; a holotype (mature); b paratype 8 (immature); c drawings of the sclerites types; $\mathbf{d}$ drawing of the radula teeth. $I$ hollow hook-shaped sclerite, $I I$ long and straight hollow acicular sclerite, $I I I$ small hollow acicular sclerite, $I V$ sigmoid

DRN-1000 $\left(43^{\circ} 53.575^{\prime} \mathrm{N} ; 08^{\circ} 56,868^{\prime} \mathrm{W}-43^{\circ} 54,015^{\prime} \mathrm{N} ; 08^{\circ} 56\right.$, 959'W), 965-974 m depth: paratypes 8 and 9 . Station DIVAArtabria I/2003 EBS-800 $\left(43^{\circ} 51.873^{\prime} \mathrm{N} ; 08^{\circ} 53,683^{\prime} \mathrm{W}\right.$ $\left.-43^{\circ} 53.120^{\prime} \mathrm{N} ; 8^{\circ} 53.301^{\prime} \mathrm{W}\right), 788-802 \mathrm{~m}$ depth: paratype 10.

\section{Etymology}

The specific name refers to the area of the Ártabro Gulf (NW Galician, NW Spain) which gave name to the hollow acicular sclerite, $V$ medially arched hollow acicular sclerite, $V I$ distally serrated hollow acicular sclerite, VII pedal-groove scale. See Fig. 2 for SEM photographs of the sclerites types

Oceanographic Expeditions in which the studied specimens were collected.

\section{Diagnosis}

Moderately thick cuticle. With epidermal papillae. Without longitudinal keels. Seven types of sclerites. Pedal fold ends at the opening of the pallial cavity. Atrial papillae simple. With dorsopharyngeal papilla gland. Distichous radula; 

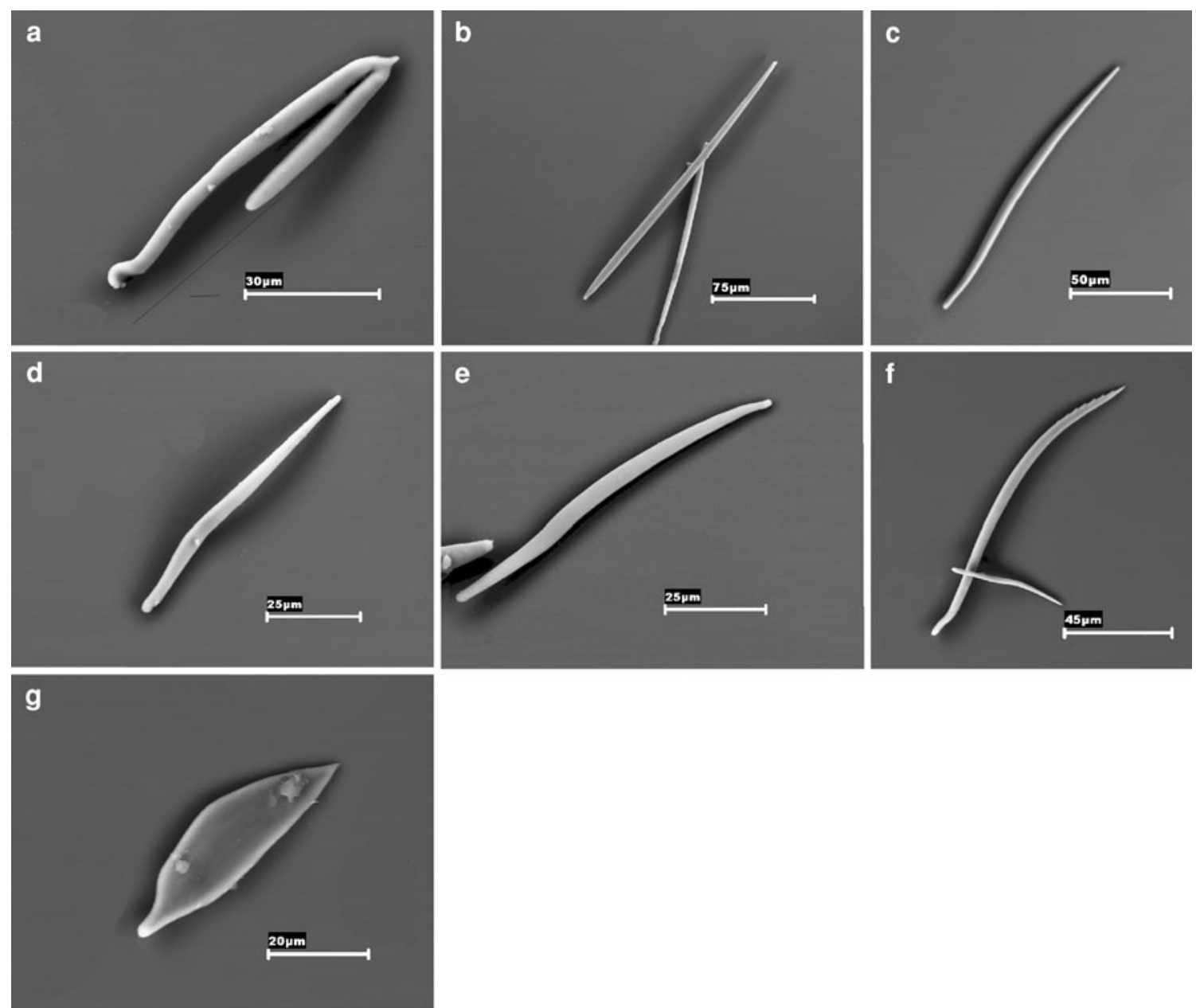

Fig. 2 SEM photographs of the sclerites types of P. artabra n. sp. a hollow hook-shaped sclerite; b long and straight hollow acicular sclerite; c small hollow acicular sclerite; d sigmoid hollow acicular

teeth with distal hook and four medial denticles. Radular sheath unpaired. Ventrolateral foregut glandular organs of ducts with subepithelially/extraepithelially arranged gland cells (type A according to Salvini-Plawen 1978 or type Pararrhopalia according to Handl and Todt 2005); ducts short and wide. Without oesophagus. Long anterodorsal midgut caecum, paired in most of its length. Seminal vesicles at gonopericardioducts. Seminal receptacles at pericardioducts. Secondary genital opening unpaired in the ventroanterior pouch of the pallial cavity. Thick suprarectal commissure, posterior to the pericardium. Up to 14 respiratory folds. Without abdominal spicules. Dorsoterminal sense organ above the anterior region of the pallial cavity.

\section{Habitus}

Vermiform specimens up to $3.2 \mathrm{~mm}$ long and $0.5 \mathrm{~mm}$ wide in the medial body region, with slightly widened body ends (Fig. 1a-b). Without lumps or longitudinal keels. Sclerites sclerite; e medially arched hollow acicular sclerite; f distally serrated hollow acicular sclerite; $g$ pedal-groove scale

obliquely and radially inserted protruding slightly from the cuticle. Pedal pit and pedal groove externally marked. Pallial cavity with subterminal opening. Yellowish-white colour after fixation and preservation in $70^{\circ}$ ethanol.

\section{Mantle}

Epidermis $(5-8 \mu \mathrm{m})$ with spherical pedunculate papillae. Moderately thick cuticle (35-50 $\mu \mathrm{m}$ thick). Blade-shaped scales (55-90 $\mu \mathrm{m}$ long, 15-18 $\mu \mathrm{m}$ wide) of pedal groove (Figs. 1c-VII, 2g) and six different types of hollow sclerites obliquely or radially inserted in 4-5 layers. Hook-shaped sclerites (90-150 $\mu \mathrm{m}$ long), with a sharp tooth in the hook curvature and with the proximal end narrow and curved; they are present along the whole dorsal body, protruding up to $40 \mu \mathrm{m}$ (Figs. 1c-I, 2a). Long, narrow and straight acicular sclerites (170-250 $\mu \mathrm{m}$ long) radially inserted in the posterior body end, from which they protrude up to $160 \mu \mathrm{m}$ (Figs. 1c-II, 2b). Small and narrow acicular sclerites, 
Fig. 3 Schematic organization of $P$. artabra n. sp. a anterior body; b posterior body. ag anterior ganglion, $a p$ atrial papillae, at atrium, $b g$ buccal ganglion, $c g$ cerebral ganglion, $c u$ cuticle, $d c$ anterodorsal midgut caecum, $d g$ dorsopharyngeal papilla gland, $d p$ dorsoanterior pouch of the pallial cavity, $d$ so dorsoterminal sense organ, go gonad, $g p$ gonopericardioduct, $\mathrm{mg}$ midgut, mo mouth, $p a$ pallial cavity, $p c$ pericardium, $p d$ pericardioduct, $p h$ pharynx, $p p$ pedal pit, $p s d$ paired spawning duct, $r a$ radula, $r e$ rectum, $r f$ respiratory fold, $r s$ radular sheath, $s c$ suprarectal commissure, $s r$ seminal receptacle, $s v$ seminal vesicle, usd unpaired spawning duct, $v f g$ ventrolateral foregut glandular organ, $v g$ ventral ganglion, $v p$ ventroanterior pouch of the pallial cavity

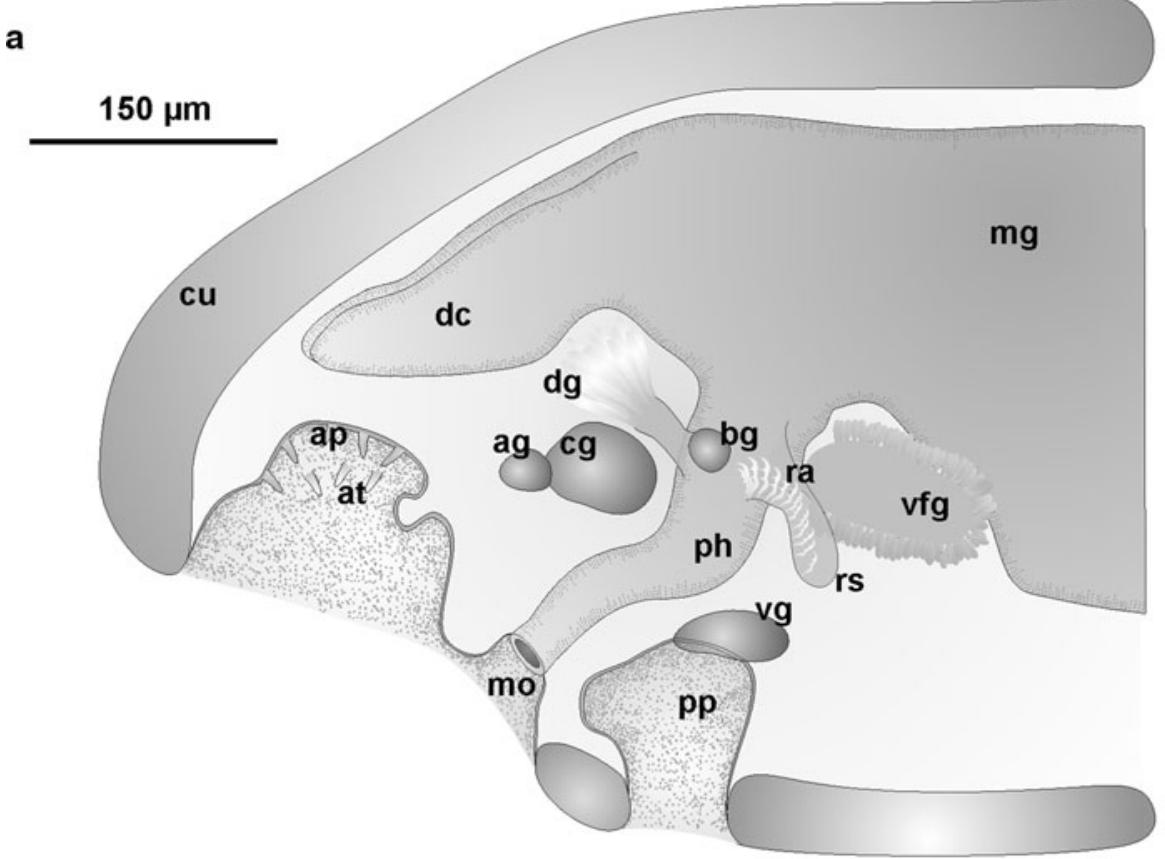

b

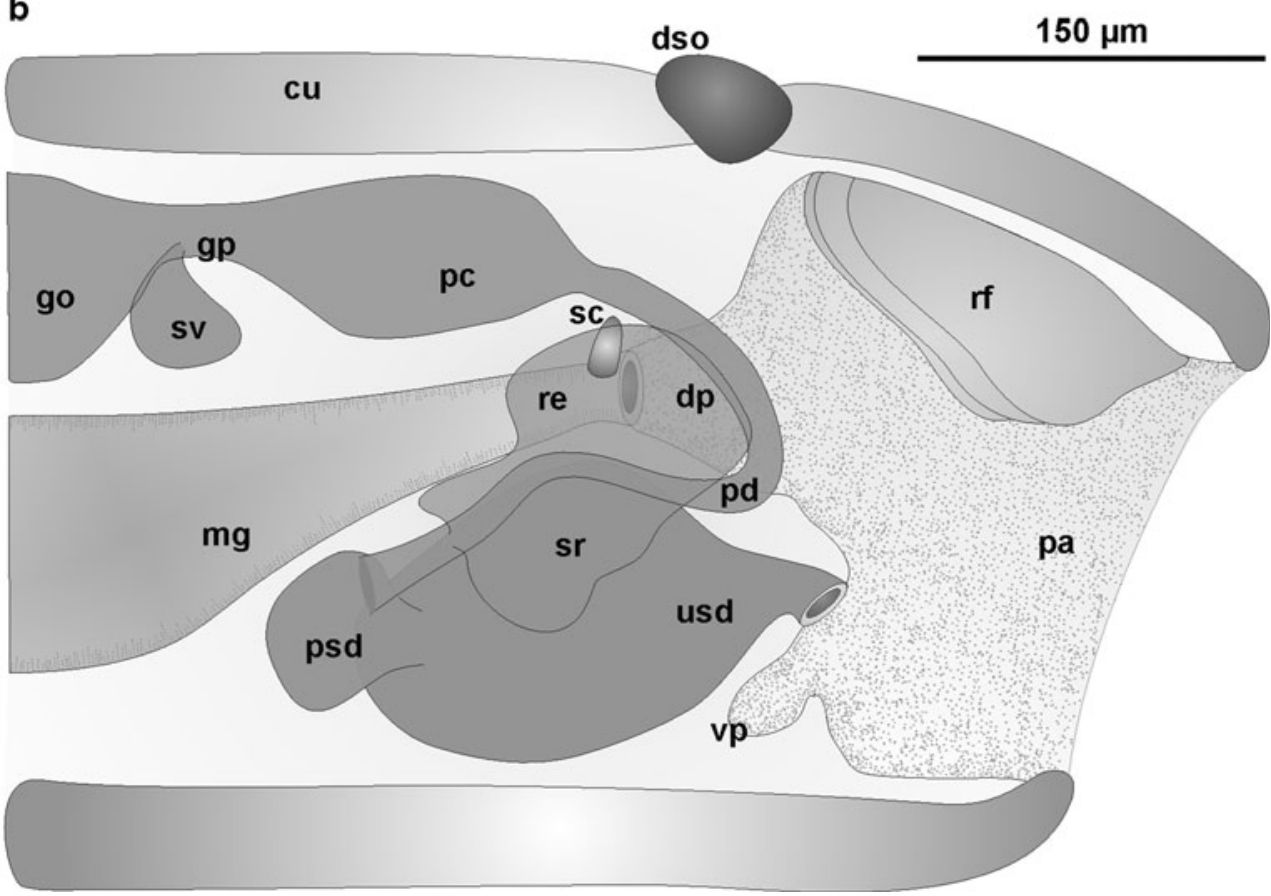

slightly curved in their medial region (30-75 $\mu \mathrm{m}$ long) (Figs. 1c-III, 2c), are obliquely inserted, more abundant in the ventral body half. Sigmoid acicular sclerites (90-200 $\mu \mathrm{m}$ long) (Figs. 1c-IV, 2d) obliquely inserted. Acicular sclerites curved in their medial region (85-175 $\mu \mathrm{m}$ long) (Figs. 1c-V, 2e) and obliquely inserted. And acicular sclerites serrated in the convex part of their distal end, with a variable number of 3-7 small teeth (100-140 $\mu \mathrm{m}$ long) (Figs. 1c-VI, 2f); they are present exclusively in the anterior body region, obliquely inserted and pointing the concave part towards the posterior body region.

\section{Pedal groove and pallial cavity}

Pedal pit $(100 \mu \mathrm{m}$ long, $110 \mu \mathrm{m}$ high, $120 \mu \mathrm{m}$ wide $)$ densely ciliated. Pedal groove with a medial ciliated fold (45 $\mu \mathrm{m}$ high, $50 \mu \mathrm{m}$ wide) that extending to opening of the 


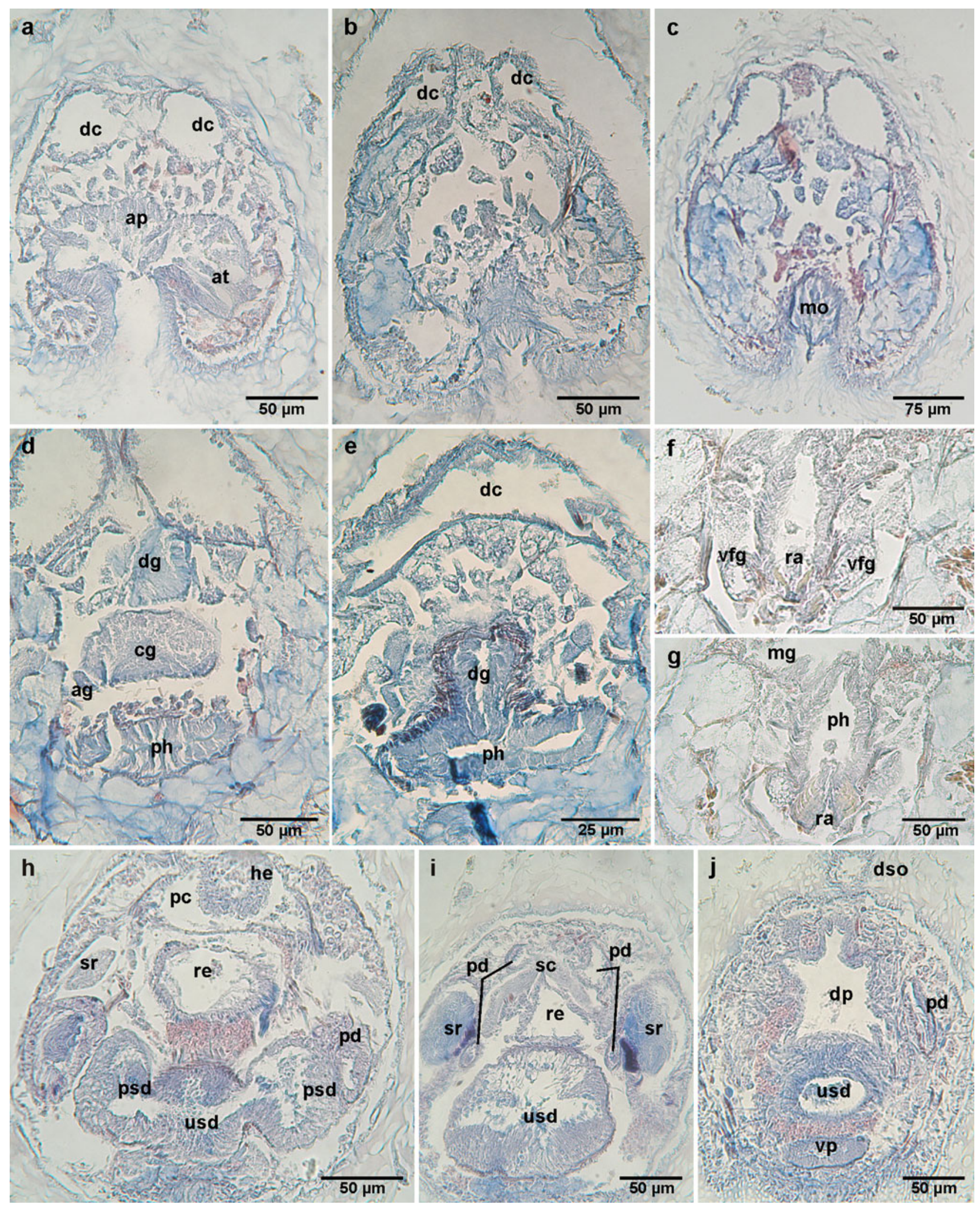

pallial cavity. The anterior follicular pedal glands opening dorsally into the pedal pit and the small posterior pedal glands along the dorsal wall of the pedal groove.
Pallial cavity with up to 14 respiratory folds radially arranged in the posterior region; the anterior region of the pallial cavity is divided into a deep dorsoanterior pouch 
4 Fig. 4 Cross sections of $P$. artabra n. sp. a atrium with sensitive papillae; b groove between atrium and mouth openings; c mouth opening; d section through the anterior region of the pharynx, showing the cerebral ganglion and the beginning of the dorsopharyngeal papilla gland; e opening of the dorsopharyngeal papilla gland into the pharynx; $\mathbf{f}-\mathbf{g}$ detail of the radula teeth and the ventrolateral foregut glandular organs; $\mathbf{h}$ section through junction of spawning ducts; i detail of the unpaired spawning duct, seminal receptacles and suprarectal commissure; $\mathbf{j}$ anterior region of pallial cavity. ag anterior ganglia, ap atrial papillae, at atrium, $c g$ cerebral ganglion, $d c$ anterodorsal midgut caecum, $d g$ dorsopharyngeal papilla gland, $d p$ dorsoanterior pouch of the pallial cavity, dso dorsoterminal sense organ, he heart, $m g$ midgut, mo mouth, $p c$ pericardium, $p d$ pericardioduct, $p h$ pharynx, $p s d$ paired spawning duct, $r a$ radula, $r e$ rectum, $s c$ suprarectal commissure, $s r$ seminal receptacle, usd unpaired spawning duct, $v f g$ ventrolateral foregut glandular organ, $v p$ ventroanterior pouch of the pallial cavity

where the rectum opens and a ventroanterior one where the unpaired secondary genital orifice dorsally opens (Figs. 3b, 4j). Without brood chambers or abdominal spicules.

\section{Nervous system and sense organs}

Cerebral ganglion unpaired with transverse section almost rectangular (70 $\mu \mathrm{m}$ long, $130 \mu \mathrm{m}$ high, $45 \mu \mathrm{m}$ wide), located dorsal to the anterior region of the pharynx. With two small anterior ganglia ( $35 \mu \mathrm{m}$ long, $40 \mu \mathrm{m}$ high, $20 \mu \mathrm{m}$ wide) whose nerves innervate the atrium and oral region (Figs. 3a, 4d). The cerebro-ventral connectives leave separately from the anterior region and the cerebrolateral leave from the posterior region of the cerebral ganglion. First ventral ganglia (70 $\mu \mathrm{m}$ long, $35 \mu \mathrm{m}$ high, $30 \mu \mathrm{m}$ wide) above the posterior region of the pedal pit and joined by a slender commissure. Buccal ganglia $(20 \mu \mathrm{m}$ long, $30 \mu \mathrm{m}$ high, $23 \mu \mathrm{m}$ maximum wide) arranged laterally to the pharynx, posteriorly to the opening of the dorsopharyngeal papilla gland (Fig. 3a). Last pair of lateral ganglia arranged laterally to the posterior region of the rectum and joined by a long suprarectal commissure (110 $\mu \mathrm{m}$ long, $10 \mu \mathrm{m}$ high, $20 \mu \mathrm{m}$ wide) posterior to the pericardium (Figs. 3b, 4i).

Atrial sense organ with up to 15 simple and thick papillae ( $40 \mu \mathrm{m}$ long, $12 \mu \mathrm{m}$ wide) (Figs. 3a, 4a). A dorsoterminal sense organ is located medially above the anterior region of the pallial cavity, prior to the beginning of the respiratory folds (Figs. 3b, 4j).

\section{Digestive system}

Mouth and atrium functionally separated. The atrial sense region is anterior and separated from the posterior buccal region by a groove with a thin epithelium but without cuticle (Figs. 3a, 4b). Dorsal to this groove there are bundles of peripheral circular muscles. Pharynx with high and slightly folded epithelium internally covered by a thin cuticular layer and externally by a thin coat of circular muscles and subepithelial glandular cells (Fig. 4d). A dorsopharyngeal papilla gland posterior to the cerebral ganglion opens dorsally into the pharynx; bodies of the glandular cells associated with the dorsal papilla are placed above the cerebral ganglion (except in immature specimens) and extend anteriorly to the atrium (Figs. 3a, 4d, e). Radula distichous with 14 pairs of radula teeth, each tooth (20-25 $\mu \mathrm{m}$ long) with a distal hook, four medial denticles and a reinforcement on its exterior margin (Figs. 1d, 4f, g). Radular sheath posterior and unpaired. Ventrolateral foregut glandular organs type A (according to Salvini-Plawen 1978) or type Pararrhopalia (corresponding to Handl and Todt 2005), as a pair of wide and short ducts encircled by musculature, with subepithelially/extraepithelially arranged gland cells along their entire length (Fig. 4f). These organs open laterally at the beginning of the radular sheath and extend posteriorly under the anterior midgut. Just two immature specimens (paratypes 7 and 8) show a short postradular oesophagus, which lacks glands and sphincter. Anterodorsal midgut caecum long and paired in the three anterior quarters of its length. Midgut with two or three sphincters in the anterior region that reduce its lumen; moreover, the midgut has well-developed lateral constrictions due to the strong dorsoventral musculature. The ciliated rectum opens into the dorsoanterior pouch of the pallial cavity, anterior to the opening of the genital orifice (Fig. 3b).

\section{Reproductive system}

Oocytes of paired gonads in posterior region (up to $50 \mu \mathrm{m}$ diameter) and formative tissue in anterior region. Short and narrow gonopericardioducts $(60 \mu \mathrm{m}$ long, $30 \mu \mathrm{m}$ high, $20 \mu \mathrm{m}$ wide) with a pair of seminal vesicles containing spermatozoids. Pericardium (140 $\mu \mathrm{m}$ long, $55 \mu \mathrm{m}$ high, $100 \mu \mathrm{m}$ wide maximum) dorsal to the rectum before its opening into the pallial cavity (Fig. 3b). Bicameral heart of oval transverse section ( $45 \mu \mathrm{m}$ high, $50 \mu \mathrm{m}$ wide), with ventricle linked with the dorsal wall and auricle free, except for its posterior end. Blood cells oval, granular and nucleated, filling the blood sinuses, mainly the ventral sinus and the sinuses that cover the region of the respiratory folds. Narrow pericardioducts $(25 \mu \mathrm{m}$ high, $15 \mu \mathrm{m}$ wide) leave the posterior end of the pericardium, extending posteriorly onto both sides of the dorsoanterior pouch of the pallial cavity. Paired seminal receptacles, containing spermatozoids, open far distally into pericardioducts (Figs. 3b, 4h, i). The two spawning ducts ( $75 \mu \mathrm{m}$ long, $75 \mu \mathrm{m}$ high, $70 \mu \mathrm{m}$ wide) fuse together into a single and voluminous oval spawning duct (170 $\mu \mathrm{m}$ long, $120 \mu \mathrm{m}$ high, $140 \mu \mathrm{m}$ wide); this unpaired duct extends anteriorly between the paired region, making up a small blind sac with unknown function 


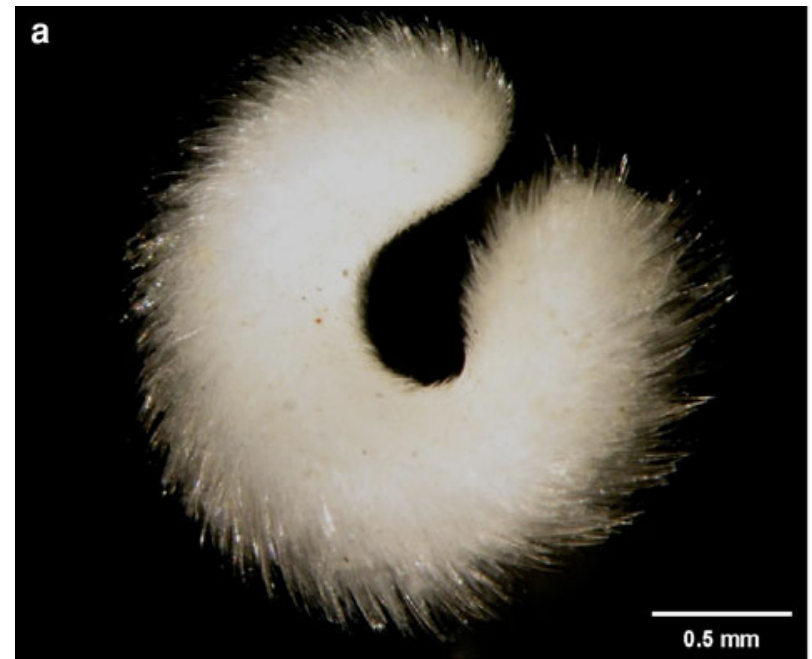

b

C
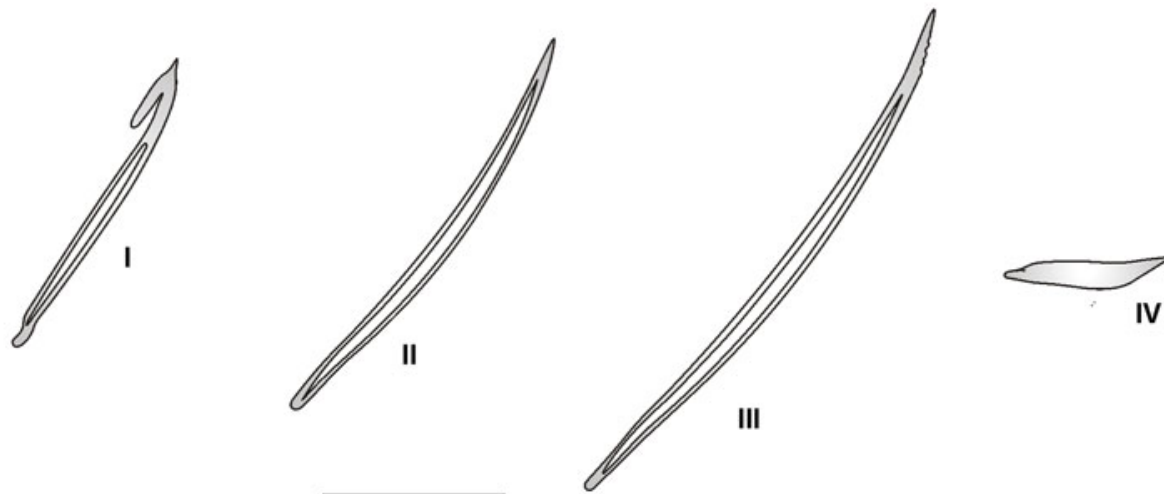

$100 \mu \mathrm{m}$

Fig. 5 Pruvotina manifesta $n$. sp. a habitus; $\mathbf{b}$ drawing of the radula teeth; c drawings of the mantle sclerites. $I$ hollow hook-shaped sclerite, $I I$ slightly curved hollow acicular sclerite, III distally serrated hollow acicular sclerite, $I V$ pedal-groove scale

(Figs. 3b, 4h). The unpaired genital opening without sphincter opens dorsally into the posterior region of the ventroanterior pouch of the pallial cavity (Figs. 3b).

Pruvotina manifesta n. sp. (Figs. 5, 6, 7)

\section{Type material}

Mature holotype in serial sections of $5 \mu \mathrm{m}$. Deposited in the Museo Nacional de Ciencias Naturales of Madrid, number MNCN 15.02/28.

Type locality

Antarctic Peninsula. Expedition Bentart-2006. Station PA 43-TA $\left(63^{\circ} 36184^{\prime} \mathrm{S} ; 64^{\circ} 2947^{\prime} \mathrm{W}\right), 254 \mathrm{~m}$ depth.

\section{Etymology}

Latin, manifestus: clear. In reference to the fact that it clearly represents the generic characteristics.

\section{Diagnosis}

$3 \mathrm{~mm} \times 0.91 \mathrm{~mm}$ specimen. Without longitudinal keels. Moderately thick cuticle $(30-40 \mu \mathrm{m})$. With epidermal papillae. Four types of sclerites. Pedal groove with one fold that does not extend into the pallial cavity. Atrial papillae simple. With dorsopharyngeal papilla gland. Radula teeth with distal hook and 5 medial denticles. Radular sheath partially paired. Ventrolateral foregut glandular organs of ducts with subepithelially/extraepithelially arranged gland cells (type A according to Salvini-Plawen 1978 or type Pararrhopalia according to Handl and Todt 2005); ducts long and tubular. With oesophagus. Anterodorsal midgut caecum frontally paired. Seminal vesicles at gonads. Seminal receptacles at spawning ducts. Secondary genital opening unpaired and ventral through a duct. Pallial cavity without pouches and without brood chambers. With 10 respiratory folds. With suprapallial glands. Without abdominal spicules. Dorsoterminal sense organ in terminal position. 
Fig. 6 Schematic organization of $P$. manifesta n. sp. a anterior body; b posterior body. ap atrial papillae, at atrium, bg buccal ganglion, $c g$ cerebral ganglion, $c u$ cuticle, $d c$ anterodorsal midgut caecum, $d g$ dorsopharyngeal papilla gland, dso dorsoterminal sense organ, go gonad, $g p$ gonopericardioduct, he heart, $l g$ lateral ganglion, $m g$ midgut, $m o$ mouth, oe oesophagus, $p a$ pallial cavity, $p c$ pericardium, $p d$ pericardioduct, $p h$ pharynx, $p p$ pedal pit, $r a$ radula, $r e$ rectum, $r f$ respiratory fold, $r s$ radular sheath, $s c$ suprarectal commissure, $s d$ spawning duct, $s g$ suprapallial glands, $s r$ seminal receptacle, $s v$ seminal vesicle, $v f g$ ventrolateral foregut glandular organ, $v g$ ventral ganglion

\section{a}

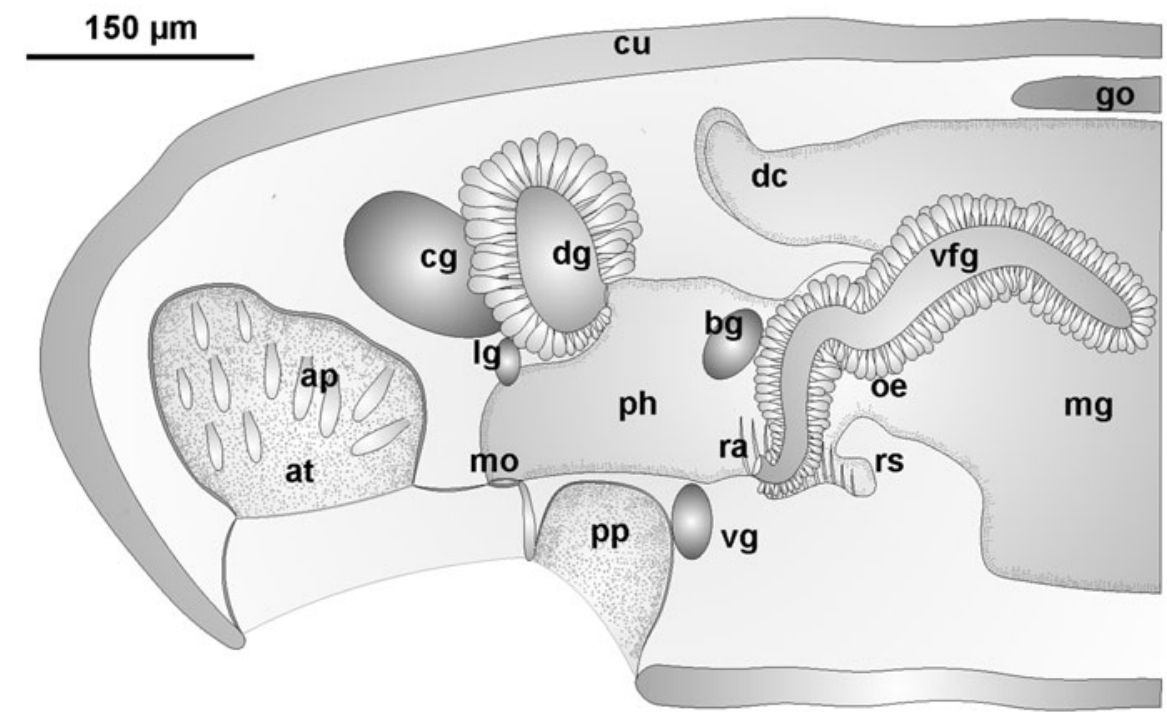

b

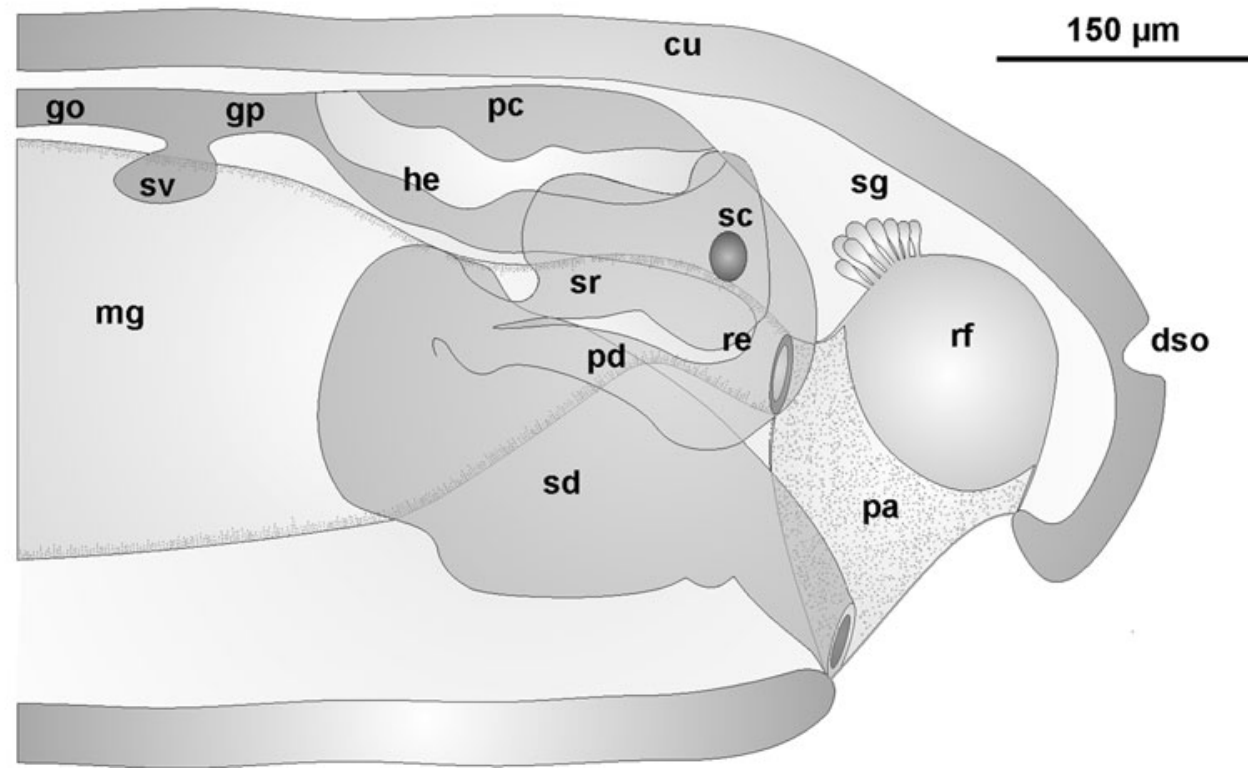

\section{Habitus}

Specimen $3 \mathrm{~mm}$ long by $0.91 \mathrm{~mm}$ thick in the medial region, with rounded anterior and posterior ends (Fig. 5a). No keel or ridge. Atriobuccal cavity, pedal groove and pallial cavity well-marked externally. Sclerites clearly protruding from the cuticle and pointing posteriorly. Colour white in $70^{\circ}$ ethanol.

\section{Mantle}

Epidermis $10 \mu \mathrm{m}$ thick with epidermal papilla. Moderately thick cuticle $(30-40 \mu \mathrm{m})$ with four types of calcareous sclerites (Fig. 5c) in oblique arrangement, leaning $60^{\circ}-70^{\circ}$, pointing posteriorly. Hollow hook-shaped sclerites $(185 \mu \mathrm{m}$ long, $8 \mu \mathrm{m}$ wide) restricted to dorsal surface. Slightly curved hollow acicular sclerites with a pointed distal end and rounded proximally ( $250 \mu \mathrm{m}$ long, $10 \mu \mathrm{m}$ wide). Slightly curved hollow acicular sclerites distally pointed and serrated and proximally rounded (325 $\mu \mathrm{m}$ long, $13 \mu \mathrm{m}$ wide). And blade-shaped scales (90 $\mu \mathrm{m}$ long) along the pedal groove.

\section{Pedal groove and pallial cavity}

Pedal groove with one pedal fold ending before opening of pallial cavity. Pallial cavity subterminal with 10 long respiratory folds radially arranged in dorsoposterior region (Figs. 6b, 7f). Pallial cavity dorsally underlain 

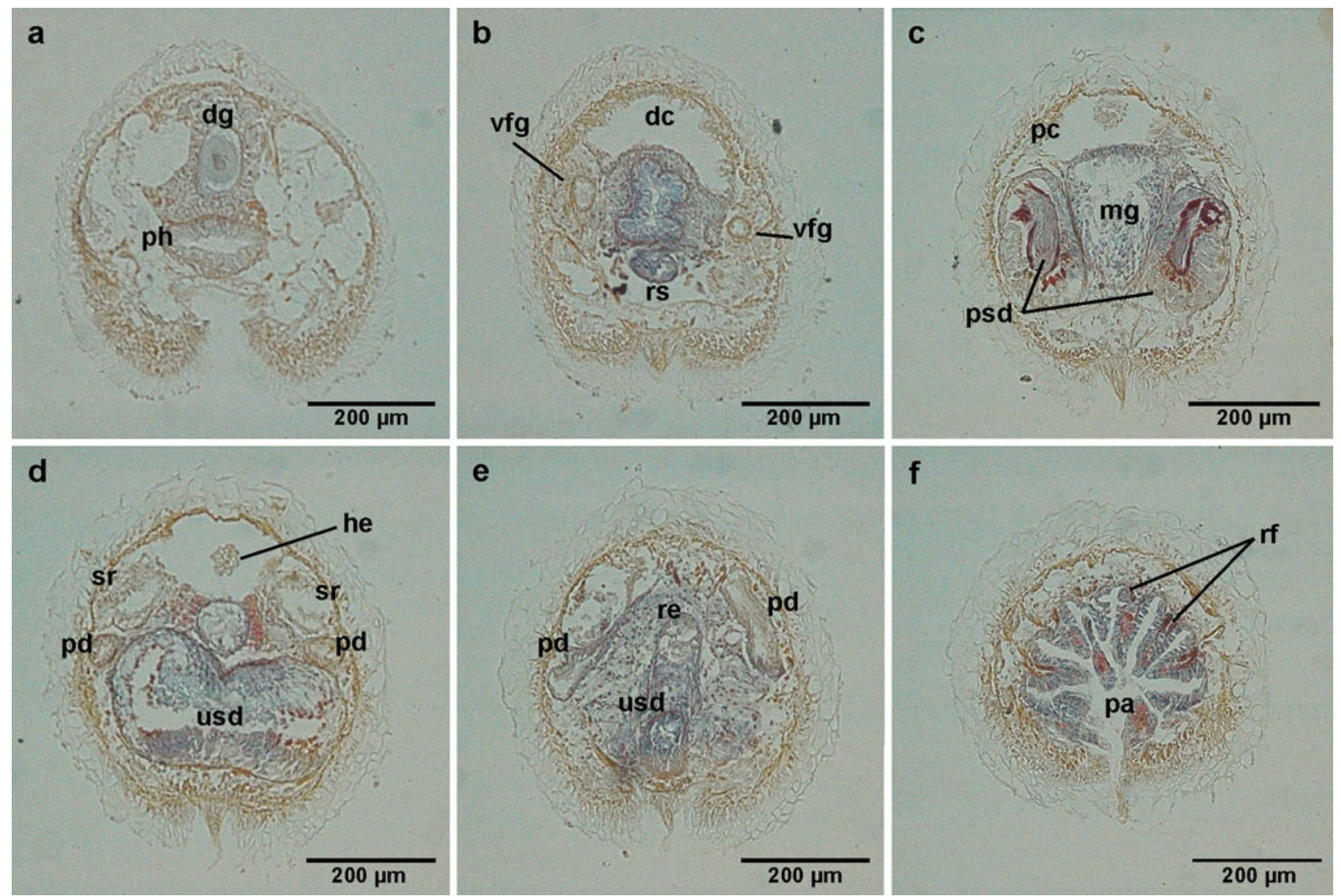

Fig. 7 Cross sections of $P$. manifesta n. sp. a detail of the anterior pharynx showing the globular body of the dorsopharyngeal papilla gland; b section through the posterior pharynx with the ventrolateral foregut glandular organs and the radular sheath; c paired spawning duct; d single spawning duct and body of the seminal receptacles; e ventral opening of the single spawning duct; $\mathbf{f}$ posterior region of the pallial cavity with respiratory folds. $d c$ anterodorsal midgut caecum, $d g$ dorsopharyngeal papilla gland, he heart, $m g$ midgut, $p a$ pallial cavity, $p c$ pericardium, $p d$ pericardioduct, $p h$ pharynx, $p s d$ paired spawning duct, $r e$ rectum, $r f$ respiratory folds, $r s$ radular sheath, $s r$ seminal receptacle, usd unpaired spawning duct, $v f g$ ventrolateral foregut glandular organ by suprapallial glands. Lacking copulatory stylets and abdominal spicules.

\section{Nervous system and sense organs}

Large atrial sense organ with simple, thick papillae. Cerebral ganglion large (50 $\mu \mathrm{m}$ long, $125 \mu \mathrm{m}$ wide, $90 \mu \mathrm{m}$ high) with a pair of lateral ganglia. First pair of ventral ganglia (60 $\mu \mathrm{m}$ diameter) ventrolateral to pharynx in posterior region of pedal pit. Buccal ganglia ( $30 \mu \mathrm{m}$ diameter) lateral in anterior radular region with a distinct ventral commissure. Suprarectal commissure lies above terminal part of rectum. Dorsoterminal sense organ at the outermost end of body.

\section{Digestive system}

Mouth separated from atrium by a ventral groove without cuticle, but with peripheral dorsal musculature. Entire pharynx with a thin circular musculature and thick coat of subepithelial pharyngeal glandular cells. A globular dorsopharyngeal papilla gland opens mediodorsally to pharynx and extends to the posterior region of cerebral ganglion (Figs. 6a, 7a). Paired ventrolateral foregut glandular organs that open into the anterior radular region; they are glandular organs type A (according to Salvini-Plawen 1978) or type Pararrhopalia (corresponding to Handl and Todt 2005), tubular and long ducts with a muscular sheath and encircled by subepithelial/extraepithelial glands along its whole length (Fig. 7b). Distichous radula made up of pairs of hooked teeth (43 $\mu \mathrm{m}$ long) with 5 medial denticles (Fig. 5b). Radular sheath ( $25 \mu \mathrm{m}$ long) divided longitudinally in its two proximal thirds by a septum of connective tissue. There is a short oesophagus with circular musculature and oesophageal glandular cells; it opens frontally into the midgut where it clearly penetrates. Midgut with welldeveloped anterodorsal caecum frontally paired and with serial lateral constrictions. Rectum tubular and narrow 
placed dorsal to spawning duct. Anus opening dorsofrontally into pallial cavity.

\section{Reproductive system}

Gonads narrow and tubular anteriorly, wider and full of oocytes and spermatozoids medially, spermatozoids more abundant posteriorly; in the posterior region the gonads have a pair of seminal vesicles, with are full of spermatozoids. Gonopericardioducts circular in transverse section opening into pericardium with a tubular heart (Fig. 7d) linked with the wall of the pericardium only by its anterior and posterior ends; a constriction divides the heart into an anterior ventricle and a posterior auricle.

The pericardioducts leave from the posterior region of the pericardium and join the dorsoanterior region of the spawning ducts. A pair of seminal receptacles (full of spermatozoids) is dorsal to and opens dorsoanteriorly into the paired spawning ducts, in the same region where the pericardioducts open (Figs. 6b, 7d). The paired spawning ducts were full of spermatozoids anteriorly; therefore they can be considered as other seminal receptacles (Fig. 7c). Medially the spawning duct is unpaired, wide and high (Fig. 7d); further posteriorly duct is tubular and narrow, opening ventrally into the pallial cavity (Fig. 7e).

Taxonomic remarks on the two new species of Pruvotina

The family Pruvotinidae is a diverse group that includes five subfamilies (see García-Álvarez and Salvini-Plawen 2007). The subfamily Pararrhopaliinae Salvini-Plawen, 1978 is characterized by the combination of the following characters: hollow hook-shaped sclerites, a dorsopharyngeal papilla gland and ventrolateral foregut glandular organs of ducts with subepithelially/extraepithelially arranged gland cells. Three genera are recognized in this subfamily: Pararrhopalia Simroth, 1893, Pruvotina Cockerell, 1903 and Labidoherpia Salvini-Plawen, 1978. P. manifesta n. sp. and P. artabra n. sp. are generically defined by the presence of midgut constrictions and respiratory folds and lack of copulatory stylets (see Table 1).

Table 1 Main difference among the genus of the subfamily Pararrhopaliinae Salvini-Plawen 1978

\begin{tabular}{llll}
\hline Genus & $\begin{array}{l}\text { Midgut } \\
\text { constrictions }\end{array}$ & $\begin{array}{l}\text { Copulatory } \\
\text { stylets }\end{array}$ & $\begin{array}{l}\text { Respiratory } \\
\text { folds }\end{array}$ \\
\hline Labidoherpia & + & + & + \\
Pararrhopalia & - & + & - \\
Pruvotina & + & - & + \\
\hline
\end{tabular}

+ Presence, - absence
Pruvotina artabra n. sp. and P. manifesta n. sp., apart from their geographical locations, have significant differences from each other: the shape or the size of their ventrolateral foregut glandular organs and dorsopharyngeal papilla glands, as well as the organization of their radular system, with double-sized radula teeth and an additional denticle per radula tooth in $P$. manifesta $\mathrm{n}$. sp. This latter also has a radular sheath proximally divided by a medial septum, whereas in P. artabra n. sp., the radular sheath is unpaired. Both species clearly differ in the organization of the spawning ducts and pallial cavity, particularly by the division in pouches in P. artabra n. sp. or the presence of suprapallial glands in P. manifesta n. sp. Other differences are the extension of the pedal fold as far as the opening of the pallial cavity in P. artabra n. sp. as well as the different positions of their respective dorsoterminal sense organs.

The main characters of the species in Pruvotina are shown in Table 2. At present, ten species are included within the genus, nine of which are described for Antarctica or for Tierra del Fuego. The only European species is Pruvotina impexa (Pruvot, 1890) known for Banyuls-sur Mer (France; 60-80 m depth). P. artabra n. sp. differs distinctly from $P$. impexa by its body size four times smaller $(P$. impexa $=12 \mathrm{~mm})$, by the mouth partially separated from the atrium, by the end of the pedal fold in the opening of the pallial cavity and by the midgut with two or three anterior sphincters and a long anterodorsal caecum frontally paired. Moreover, P. artabra n. sp. has seminal vesicles at the gonopericardioducts, absent in $P$. impexa, and a different arrangement of the pallial cavity (Pruvot 1890, 1891). In addition, P. artabra n. sp. differs from $P$. impexa by the length and the posterior position to the pericardium of the suprarectal commissure and by the position of the dorsoterminal sense organ above the anterior region of the pallial cavity (Table 2).

Compared with the other known species, the anatomical features of P. artabra n. sp. place it close to Pruvotina peniculata Salvini-Plawen, 1978, with which it shares characters such as a similar organization of the anterior region of the midgut, the opening of the genital orifice into the ventroanterior pouch of the pallial cavity and the absence of brood chambers (Salvini-Plawen 1978). However, $P$. artabra n. sp. differs from $P$. peniculata in the absence of a middorsal crest of sclerites, suprapallial glands and abdominal spicules, with simple atrial papillae instead of grouped papillae, a completely unpaired radular sheath, with seminal vesicles at the gonopericardioducts and more respiratory folds than $P$. peniculata. Other specific differences are the anterior position of the dorsoterminal sense organ as well as the posterior position of the suprarectal commissure in P. artabra n. sp. (Table 2).

Finally, P. artabra n. sp. differs from all species of the genus, except for Pruvotina pallioglandulata Salvini- 


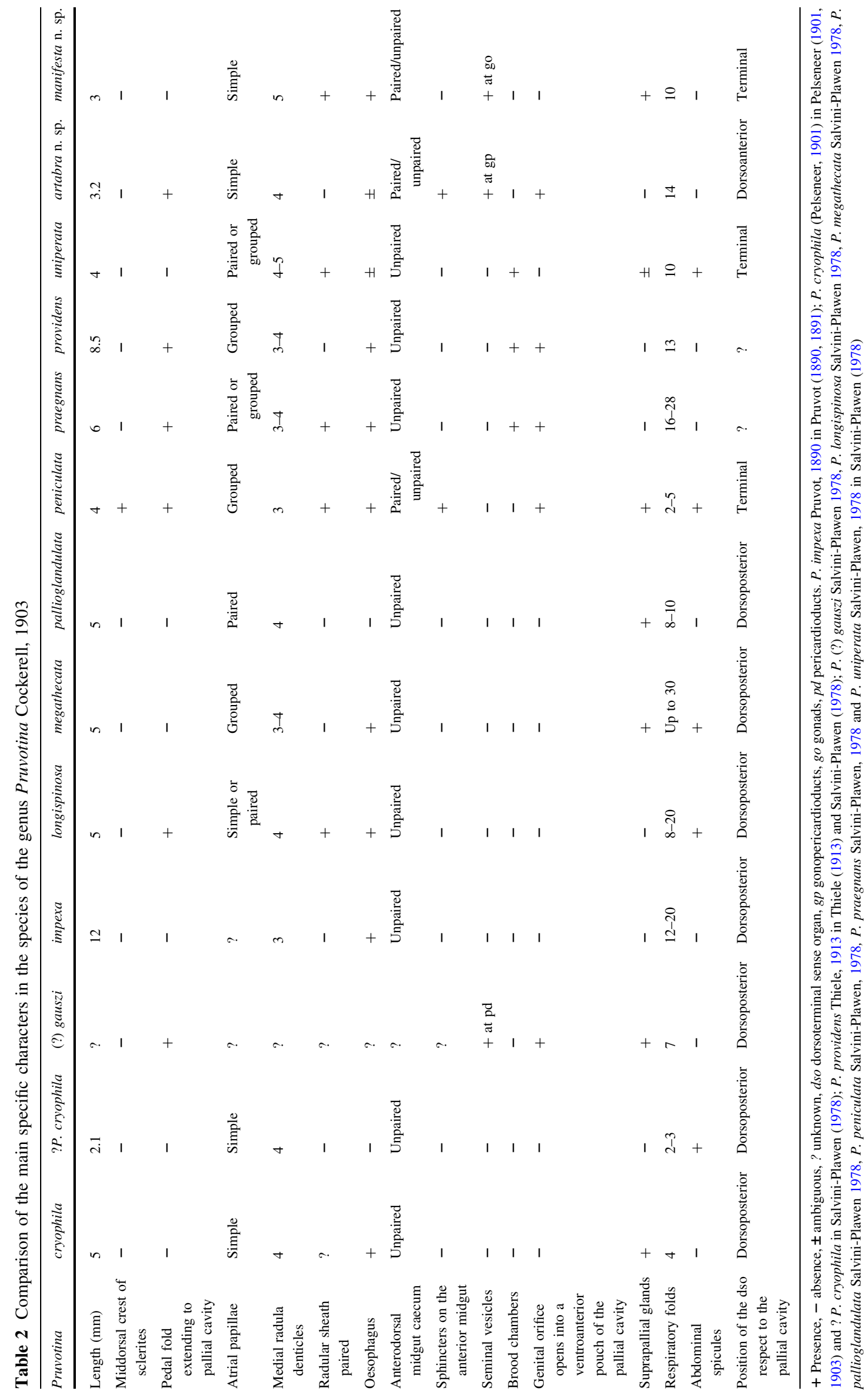


Plawen, 1978 and Pruvotina uniperata Salvini-Plawen, 1978, in lacking an oesophagus (Salvini-Plawen 1978). However, this character should be taken into account with some reservation, for there is a short postradular oesophagus in two immature specimens of P. artabra n. sp.; the variability on the oesophagus presence also has been reported in other species of Solenogastres as $P$. uniperata (Salvini-Plawen 1978).

Pruvotina manifesta $\mathrm{n}$. sp. is distinguished from $P$. impexa by geographical distance, by its significantly smaller body size with the posterior end of the body not truncated, by the separation of the mouth and atrium and by the bulbous dorsopharyngeal papilla gland. In addition, $P$. manifesta n. sp. has two additional medial denticles per radula tooth, a radular sheath partially divided, and the anterodorsal midgut caecum is frontally paired. Moreover, $P$. manifesta n. sp. but not $P$. impexa has suprapallial glands.

Of the 9 Antarctic and Subantartic species, Pruvotina longispinosa Salvini-Plawen, 1978, P. pallioglandulata, Pruvotina praegnans Salvini-Plawen 1978 and P. uniperata, are present in the South Shetland Islands (SalviniPlawen 1978), the same biogeographical area as $P$. manifesta n. sp. The new species differs from $P$. praegnans and $P$. uniperata in having an anterodorsal midgut caecum frontally paired and lacking brood chambers. Moreover, $P$. praegnans has fewer medial radula denticles, different organization of the pallial cavity, and no suprapallial glands and seminal vesicles present in P. manifesta n. sp., and $P$. uniperata has abdominal spicules absents in P. manifesta n. sp.

Pruvotina longispinosa and $P$. pallioglandulata have foregut ventral glandular organs with short ducts and an unpaired anterodorsal midgut caecum; besides, P. longispinosa has abdominal spicules and lacks suprapallial glands, and the pedal fold ends at the opening of the pallial cavity. In addition, $P$. pallioglandulata has an undivided radular sheath and lacks an oesophagus, the opening of the spawning duct is axial and wide and the pallial cavity has a dorsoanterior pouch absent in P. manifesta $\mathrm{n}$. sp.

As regards the other 5 species, they have significant differences with $P$. manifesta n. sp. in the structure of their respective pallial cavities. In particular, Pruvotina (?) gauszi Salvini-Plawen 1978, Pruvotina megathecata Salvini-Plawen 1978, P. peniculata and Pruvotina providens Thiele, 1913, have a pallial cavity arranged in pouches and $P$. providens furthermore has two brood chambers. $P$. manifesta n. sp. also differs from $P$. peniculata in lacking a middorsal crest of sclerites, having a larger number of medial radula denticles, and lacking sphincters on the anterior midgut, possessing seminal vesicles and lacking abdominal spicules. And finally, Pruvotina cryophila (Pelseneer, 1901) has fewer respiratory folds, an unpaired anterodorsal midgut caecum and an unpaired radular sheath.

\section{Subfamily Eleutheromeniinae Salvini-Plawen 1978}

With hollow hook-shaped sclerites. Ventrolateral foregut glandular organs of ducts with subepithelially/extraepithelially arranged gland cells. Without dorsopharyngeal gland.

\section{Genus Gephyroherpia Salvini-Plawen 1978}

With epidermal papillae. Mouth opening separated from the atrium. With distichous radula. Secondary genital opening unpaired. Without copulatory stylets. With dorsoterminal sense organ. With respiratory organs.

TYPE SPECIES Gephyroherpia antarctica Salvini-Plawen 1978.

Gephyroherpia impar n. sp. (Figs. 8, 9, 10, 11)

\section{Type material}

Mature holotype cut in serial sections of $5 \mu \mathrm{m}$. Deposited in the Museo de Historia Natural of the University of Santiago de Compostela, number MHN USC 10010.

Type locality

NW Galicia (NW Spain). Expedition DIVA-Artabria I/2003. Station DIVA-Artabria I/2003 EBS-600 (4348. $587^{\prime} \mathrm{N}$; $\left.08^{\circ} 51.402^{\prime} \mathrm{W}-43^{\circ} 49.545^{\prime} \mathrm{N} ; 08^{\circ} 51.497^{\prime} \mathrm{W}\right), 598-610 \mathrm{~m}$ depth.

\section{Etymology}

Latin impar: unpaired. Referring to the unpaired anterodorsal midgut caecum.

\section{Diagnosis}

Cuticle up to $50 \mu \mathrm{m}$ thick; spicules in several layers. With epidermal papillae. With middorsal keel. Atrial sense organ posteriorly trilobed, central region forming a blind pouch that exceeds the lateral ones; single or paired atrial papillae. One pedal fold that not extends into the pallial cavity. Hooked radula teeth without medial denticles. Radular sheath unpaired. Ventrolateral foregut glandular organs of ducts with subepithelially/extraepithelially arranged gland cells (type A according to Salvini-Plawen 1978 or type Pararrhopalia according to Handl and Todt 2005); ducts long. Oesophagus with glands. Unpaired anterodorsal midgut caecum. Midgut without lateral constrictions. Pericardioducts distally with seminal receptacles. Secondary 


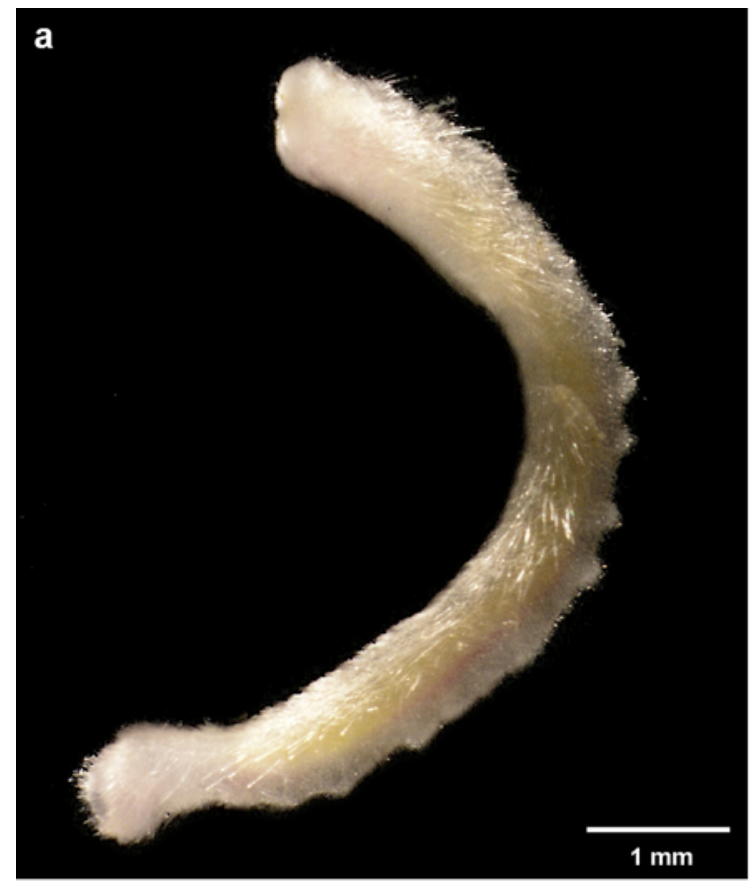

b
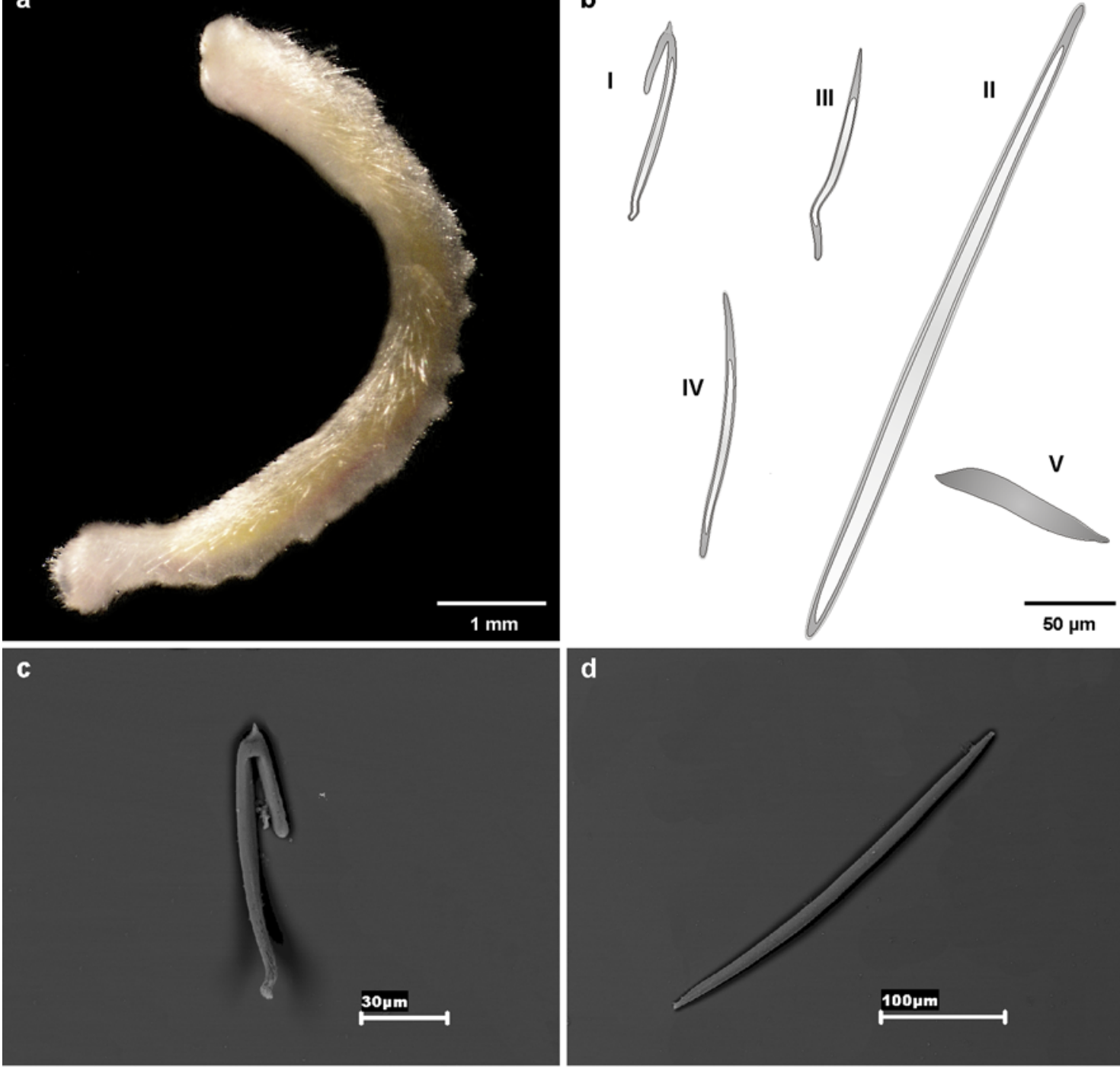

d
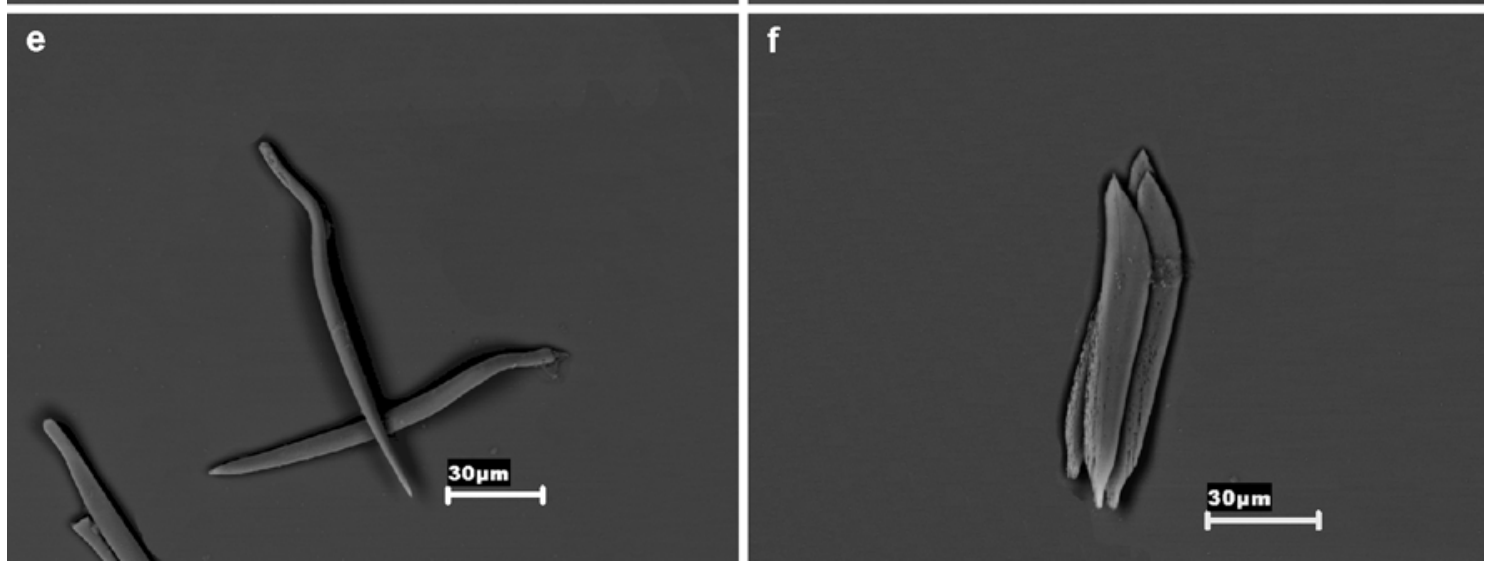

Fig. 8 Gephyroherpia impar n. sp. a habitus; b drawings of the sclerites types; c-f SEM photographs of several types of sclerites; c hollow hook-shaped sclerite; d long hollow acicular sclerite; e sigmoid hollow acicular sclerite; f pedal-groove scale. $I$ hollow

hook-shaped sclerite, II long hollow acicular sclerite, III sigmoid hollow acicular sclerite, $I V$ medially curved hollow acicular sclerite, $V$ pedal-groove scale 
Fig. 9 Schematic organization of G. impar n. sp. a anterior body; b posterior body. ag anterior ganglion, ap atrial papillae, at atrium, bg buccal ganglion, $c g$ cerebral ganglion, $c u$ cuticle, $d c$ anterodorsal midgut caecum, dso dorsoterminal sense organ, go gonad, $g p$ gonopericardioduct, he heart, $l g$ lateral ganglion, $m g$ midgut, mo mouth, oe oesophagus, og genital orifice, $p a$ pallial cavity, $p c$ pericardium, $p d$ pericardioduct, $p h$ pharynx, $p p$ pedal pit, $r a$ radula, re rectum, $r f$ respiratory fold, $r s$ radular sheath, $s c$ suprarectal commissure, $s d$ spawning duct, $s r$ seminal receptacle, $v f g$ ventrolateral foregut glandular organ, $v g$ ventral ganglion, $v p$ ventroanterior pouch of the pallial cavity

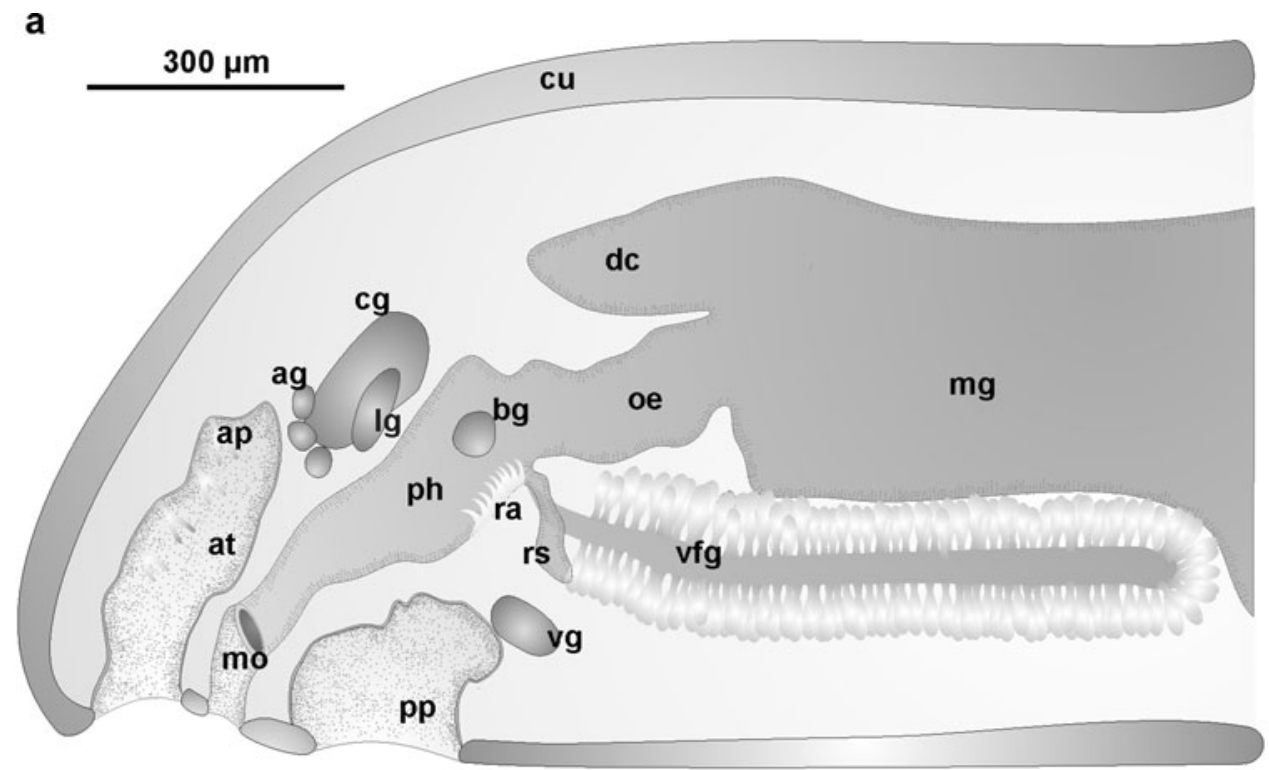

b $300 \mu \mathrm{m}$

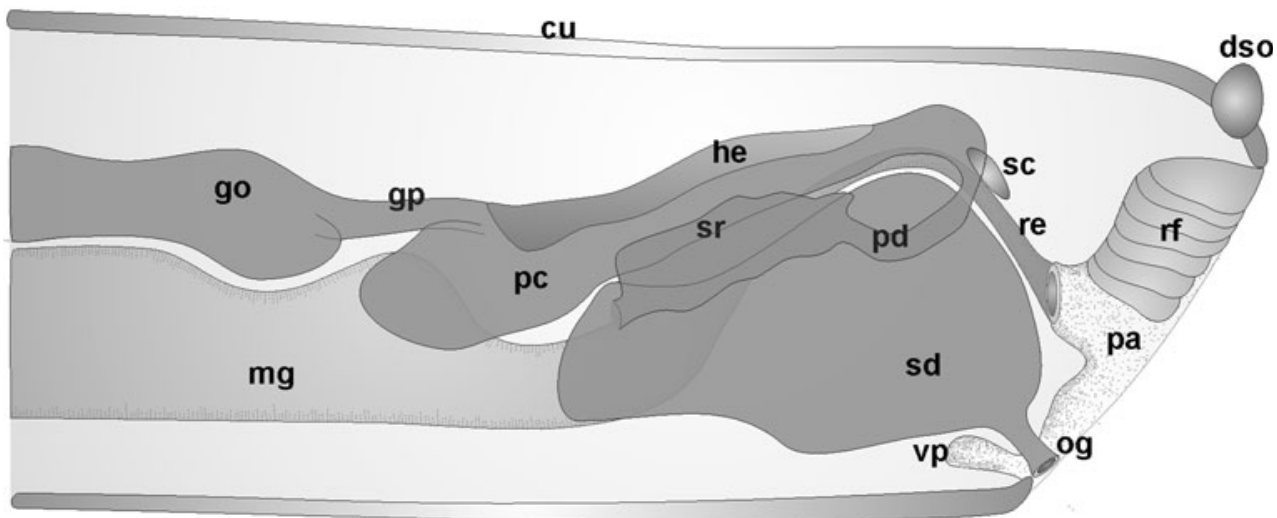

genital opening unpaired and ventral. With 15 respiratory folds. Without abdominal spicules.

\section{Habitus}

Vermiform specimen $7 \mathrm{~mm}$ long and $0.8 \mathrm{~mm}$ high in the medial body region. With a well-marked and continuous middorsal keel which varies somewhat in its height along its course and shows, in the medial body region, 10 lobulations (Fig. 8a). Sclerites obliquely and radially inserted. Pedal groove externally marked. Yellowish-white colour after fixation and preservation in $70^{\circ}$ ethanol.

\section{Mantle}

Epidermis (10-12.5 $\mu \mathrm{m}$ thick) with spherical epidermal papillae. Thick cuticle $(40-50 \mu \mathrm{m}$ thick) with sclerites arranged in 4 layers. Continuous middorsal keel with isosceles triangle transverse section more marked in the four anterior lobulations; the keel not extending as far as the body ends, beginning at the pharynx level and ending at the level of the medial region of the spawning ducts.

With 5 types of mantle sclerites (Fig. 8b). Hollow hookshaped sclerites with curved proximal end and a sharp tooth in the curvature of the hook (80-100 $\mu \mathrm{m}$ long, 6-8 $\mu \mathrm{m}$ wide) (Fig. 8b-I, c); limited to dorsal body region and radially inserted. Long hollow acicular sclerites, straight or slightly curved medially (350-450 $\mu \mathrm{m}$ long, 13-15 $\mu \mathrm{m}$ wide); obliquely inserted in the cuticle (Fig. 8bII, d). Hollow acicular sclerites sigmoid near their proximal end (100-180 $\mu \mathrm{m}$ long, 6-8 $\mu \mathrm{m}$ wide) (Fig. 8b-III, e); obliquely inserted. Hollow acicular sclerites slightly curved in their medial region (120-180 $\mu \mathrm{m}$ long, 6-9 $\mu \mathrm{m}$ wide); obliquely inserted (Fig. 8b-IV). And blade-shaped scales (90-95 $\mu \mathrm{m}$ long, 15-18 $\mu \mathrm{m}$ maximum wide) on both sides of the pedal groove (Fig. 8b-V, f). 


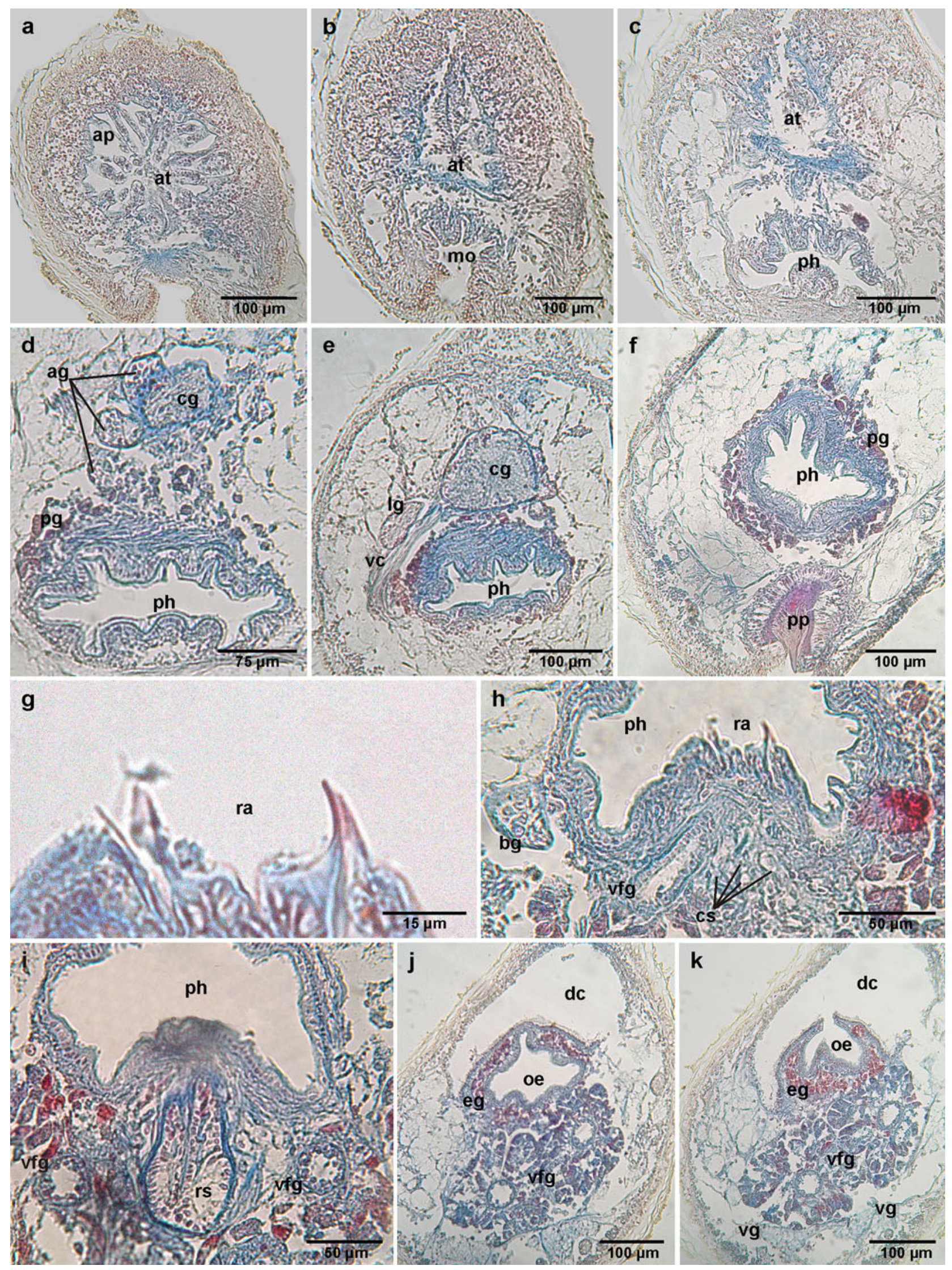


4 Fig. 10 Cross sections through the anterior body of G. impar n. sp. a anterior region of the atrium with papillae; b-c posterior region of the atrium with the central lobe extending above the anterior pharynx; d detail of the anterior ganglia; $\mathbf{e}$ origin of cerebro-ventral connective; $\mathbf{f}$ cross section through preradular pharynx and pedal pit; $\mathbf{g}-\mathbf{h}$ radula opening into pharynx; $\mathbf{g}$ pair of radula teeth; $\mathbf{h}$ radular support cells and ventrolateral foregut glandular organs; $\mathbf{i}$ radular sheath; $\mathbf{j}-\mathbf{k}$ oesophageal region. ag anterior ganglion, $a p$ atrial papillae, at atrium, $b g$ buccal ganglion, $c g$ cerebral ganglion, $c s$ radular support cells, $d c$ anterodorsal midgut caecum, eg oesophageal glands, $l g$ lateral ganglion, mo mouth, oe oesophagus, $p g$ pharyngeal glands, $p h$ pharynx, $p p$ pedal pit, $r a$ radula tooth, $r s$ radular sheath, $v c$ cerebroventral connective, $v f g$ ventrolateral foregut glandular organ, $v g$ ventral ganglion

\section{Pedal groove and pallial cavity}

Wide pedal pit (170 $\mu \mathrm{m}$ high, $120 \mu \mathrm{m}$ wide) located below the anterior region of the pharynx and provided with a strongly ciliated epithelium (Fig. 10f). Pedal groove (75 $\mu \mathrm{m}$ high, $80 \mu \mathrm{m}$ wide) with a ciliated fold $(60 \mu \mathrm{m}$ high, $50 \mu \mathrm{m}$ wide) ending before the opening of the pallial cavity. A pair of follicular anterior pedal glands opens into the pedal pit and some small posterior pedal glands open along the pedal groove.

The pallial cavity opens subterminally. Dorsoposterior region of pallial cavity with 15 respiratory folds radially arranged (Fig. 11i). In the anterior region, the unpaired genital orifice opens ventrally whereas the dorsal region receives the opening of the rectum (Figs. 9b, 11g, h); a short ventroanterior pouch is formed in front of the genital orifice. Without suprapallial glands and abdominal spicules.

\section{Nervous system and sense organs}

Cerebral ganglion (140 $\mu \mathrm{m}$ long, $120 \mu \mathrm{m}$ high, $150 \mu \mathrm{m}$ wide) with trapezoidal transverse section, dorsally to the preradular region of the pharynx; with three pairs of small anterior ganglia of oval transverse section $(30 \mu \mathrm{m}$ diameter), almost fused with the cerebral ganglion (Figs. 9a, 10d). Connectives leave the cerebral ganglion separately, but close. Thick cerebro-ventral connectives $(20 \mu \mathrm{m}$ wide $)$ (Fig. 10e) leave the ventrolateral margins of the cerebral ganglion to connect with the first pair of ganglia of the ventral nervous cords (120 $\mu \mathrm{m}$ long, $40 \mu \mathrm{m}$ high, $50 \mu \mathrm{m}$ wide) arranged above the posterior region of the pedal pit and joined by a $10 \mu \mathrm{m}$ wide pedal commissure. Short cerebro-lateral connectives $(80 \mu \mathrm{m}$ long, $10 \mu \mathrm{m}$ wide) leave the cerebral ganglion separately, lateroventrally and join the first pair of ganglia of the lateral nervous cords (40 $\mu \mathrm{m}$ long, $70 \mu \mathrm{m}$ high, $40 \mu \mathrm{m}$ wide) (Figs. 9a, 10e). Finally, the cerebro-buccal connectives (10 $\mu \mathrm{m}$ wide) leave ventrolaterally the cerebral ganglion to connect with the pair of buccal ganglia $(50 \mu \mathrm{m}$ long, $50 \mu \mathrm{m}$ high, $30 \mu \mathrm{m}$ wide) arranged on both sides of the pharyngeal radular region; buccal ganglia joined by a commissure ( $5 \mu \mathrm{m}$ wide) ventral to the pharynx, anterior to the radular sheath. Last pair of lateral ganglia above the medial region of the rectum; they are joined by a short suprarectal commissure as thick as the ganglia themselves ( $35 \mu \mathrm{m}$ long, $20 \mu \mathrm{m}$ wide).

Atrial sense organ represents a separate cavity from the mouth; it shows numerous papillae (75 $\mu \mathrm{m}$ long, $10 \mu \mathrm{m}$ wide) simple or in pairs placed on the lateral and dorsal walls (Fig. 10a). The posterior region of the atrium has a trilobed section, whose central part without papillae continues posteriorly making up a short pouch dorsal to the anterior pharynx (Fig. 10b, c). Dorsoterminal sense organ dorsal to the posterior end of the pallial cavity (Fig. 11i).

\section{Digestive system}

Mouth opening distinctly separated from atrium by a cuticularized groove with peripheral muscles. Preradular pharynx with folded epithelium ( $25 \mu \mathrm{m}$ thick) surrounded by a thin envelope of circular muscles and a layer of subepithelial glandular cells with cytoplasm loaded with granules that get red with Mallory's trichromic (Fig. 10f); both increase their thickness posteriorly. There is no dorsopharyngeal gland. In the radular region of the pharynx, the muscular envelope gets thinner and the subepithelial glandular cells are replaced by a pair of ventrolateral foregut glandular organs made up two long ducts enveloped by muscle fibres, into which many subepithelial/extraepithelial gland cells open intercellularly (type A according to Salvini-Plawen 1978; type Pararrhopalia corresponding to Handl and Todt 2005). The ducts of these ventrolateral foregut glandular organs $(30-40 \mu \mathrm{m}$ diameter) open ventrally into the pharynx, in front of the radular sheath and extend posteriorly under the anterior midgut (Figs. 9a, 10h-k). Distichous radula with 12 pairs of teeth $(30 \mu \mathrm{m}$ high, $20 \mu \mathrm{m}$ wide) with a distal hook $(12 \mu \mathrm{m}$ high) and without medial denticles (Fig. 10g, h). Radular sheath unpaired along its whole length and encircled by a weak wrapping of circular muscles. Radular support made up of 6 pairs of small turgescent cells (Fig. 10h).

Long postradular oesophagus opening ventrally into anterior midgut; oesophagus lacks sphincter, but shows a dense envelop of subepithelial glandular cells similar to those of the preradular pharyngeal region (Fig. 10j, k). Midgut without serial constrictions but with a long and wide anterodorsal caecum $(225 \mu \mathrm{m}$ long, $60 \mu \mathrm{m}$ high, $175 \mu \mathrm{m}$ maximum width) placed above the oesophagus. Rectum opens frontodorsally into pallial cavity, anterior to the secondary genital orifice.

\section{Reproductive system}

Long and tubular gonads with oocytes (up to $40 \mu \mathrm{m}$ diameter) along its whole length. Posteriorly, the gonads 

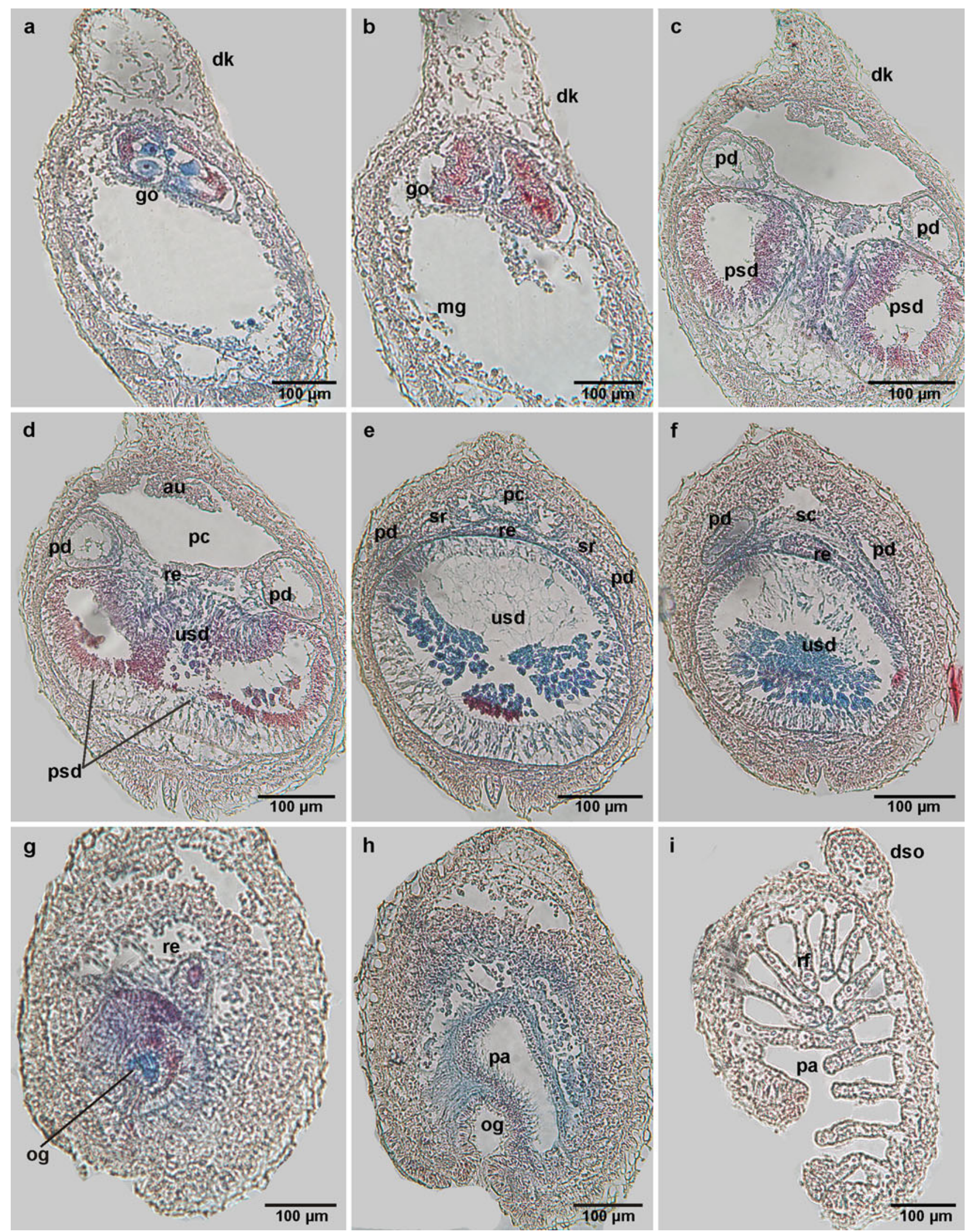
4 Fig. 11 Cross sections through the posterior body of G. impar n. sp. $\mathbf{a}$ anterior region of the gonads with oocytes; $\mathbf{b}$ posterior region of the gonads with spermatozoa; c paired spawning duct; $\mathbf{d}$ fusion of the spawning ducts; e-f unpaired spawning duct; $\mathbf{g}-\mathbf{h}$ anterior region of the pallial cavity with the ventral opening of the genital orifice; i detail of the posterior region of the pallial cavity with respiratory folds. $a u$ auricle, $d k$ middorsal keel, dso dorsoterminal sense organ, go gonad, $m g$ midgut, og genital orifice, $p a$ pallial cavity, $p c$ pericardium, $p d$ pericardioduct, $p s d$ paired spawning duct, re rectum, $r f$ respiratory fold, $s c$ suprarectal commissure, $s r$ seminal receptacle, usd unpaired spawning duct

form a pair of pouches where spermatozoa accumulate, functioning as seminal vesicles. Gonopericardioducts laterally ciliated ( $200 \mu \mathrm{m}$ long, $50 \mu \mathrm{m}$ high, $40 \mu \mathrm{m}$ wide) opening dorsofrontally into a voluminous pericardium (675 $\mu \mathrm{m}$ long, $140 \mu \mathrm{m}$ high, $250 \mu \mathrm{m}$ wide) whose ventroanterior part extends under the gonopericardioducts (Fig. 9b). Bicameral heart (425 $\mathrm{m}$ long, $40 \mu \mathrm{m}$ high, $100 \mu \mathrm{m}$ wide), partially bilobed, as an invagination of the dorsal wall of the pericardium (Fig. 11d). Pericardioducts (170 $\mu \mathrm{m}$ long, $45 \mu \mathrm{m}$ high, $20 \mu \mathrm{m}$ wide) leave from the posterior region of the pericardium and opening dorsally into the anterior region of the spawning ducts; before opening into the spawning ducts, the pericardioducts widen and contain spermatozoids, here they functioning as seminal receptacles. Spawning ducts with high and glandular epithelium along its whole length. The anterior region of the spawning duct is paired $(220 \mu \mathrm{m}$ long, $85 \mu \mathrm{m}$ high, $75 \mu \mathrm{m}$ wide), fusing distally to form a large single duct (325 $\mu \mathrm{m}$ long, $300 \mu \mathrm{m}$ high, $350 \mu \mathrm{m}$ wide) that dislodges the rest of internal organs towards the dorsal body area (Fig. 11e, f). Genital orifice with sphincter opens ventrally at the beginning of the pallial cavity opening (Fig. 11g). There are no copulatory stylets.

\section{Taxonomic remarks}

Gephyroherpia impar n. sp. belongs to the order Cavibelonia Salvini-Plawen 1978, because it presents hollow acicular sclerites and is included in the family Pruvotinidae Salvini-Plawen 1978, for having a distichous radula and a pair of ventrolateral foregut glandular organs of ducts with subepithelially/extraepithelially arranged gland cells. The new species is classified within the genus Gephyroherpia Salvini-Plawen 1978, because having a thick cuticle with epidermal papillae, a mouth clearly separated from the atrium and a distichous radula and lacking copulatory stylets.

Two other Gephyroherpia species are currently known: Gephyroherpia antarctica Salvini-Plawen 1978 from Ross Sea and Davis Sea (342-714 m) and Gephyroherpia (?) triangulata Salvini-Plawen, 2009 from the Irish Sea $(78 \mathrm{~m})$ (Salvini-Plawen 1978, 2009). G. impar n. sp. differs from both species in having oesophageal glands, an unpaired anterodorsal midgut caecum and lacking midgut constrictions.

Gephyroherpia (?) triangulata was described from an immature specimen and the anatomical characteristics of its posterior region are still unknown; however, this species is closer to G. impar n. sp. than to G. antarctica as regards its biogeographical distribution, although it comes from a much shallower depth. G. impar n. sp. and G. (?) triangulata have an atrium posteriorly trilobed, radula teeth without medial denticles and long ventrolateral foregut glandular organs, characters that differentiate them clearly from G. antarctica. Moreover, both species exhibit a middorsal keel that gives them a triangular transverse section, but in G. impar n. sp. the keel has lobulations absent in $G$. (?) triangulata. Nevertheless, there are additional differences between $G$. impar n. sp. and $G$. (?) triangulata. G. impar n. sp. has epidermal papillae and their pedal fold ends before the opening of pallial cavity; it has hooked radula teeth; and their radular sheath is not divided proximally. Besides, G. (?) triangulata lacks respiratory folds, although according to Salvini-Plawen (2009), the absence of respiratory folds may be due to the juvenile state.

Regarding $G$. antarctica, G. impar n. sp. also differs because it lacks the abdominal spicules and the suprapallial glands which presents $G$. antarctica and by the modification of the pericardioducts serving as seminal receptacles in G. impar $n$. sp. The diagnostic characters for all species of Gephyroherpia are shown in Table 3.

\section{General conclusions}

In spite of the last reviews made (Salvini-Plawen 1978; García-Álvarez and Salvini-Plawen 2007), the systematics of Solenogastres still presents some problems. The descriptions are sometimes incomplete, and different characters that are considered taxonomically relevant at present were not taken into account in the oldest descriptions. Besides, the histological conditions of the very few specimens available for research do not often allow making detailed descriptions, which makes more difficult the study of the species.

In this context, one of the generic characters used is the position of the mouth opening, sharing a common cavity either with the atrium (common atriobuccal cavity) or as an independent cavity (buccal cavity). In the diagnosis of the genus Pruvotina Cockerell, 1903, the "mouth opening (in part separated from atrium but) within the common atrio-buccal opening" (García-Álvarez and Salvini-Plawen 2007), is an ambiguous, variable and badly defined character. In this way, in some species of Pruvotina, the mouth 
Table 3 Differences among the species of the genus Gephyroherpia Salvini-Plawen 1978

+ Presence, - absence,

? unknown. G. antarctica

Salvini-Plawen 1978 in Salvini-

Plawen (1978); G. (?)

triangulata Salvini-Plawen,

2009 in Salvini-Plawen (2009)

\begin{tabular}{|c|c|c|c|}
\hline Gephyroherpia & antarctica & (?) triangulata & impar n. sp. \\
\hline Distribution & $\begin{array}{l}\text { Antarctica } \\
\text { Ross Sea, 342-714 m } \\
\text { Davis Sea, } 385 \mathrm{~m}\end{array}$ & $\begin{array}{l}\text { Irish Sea } \\
78 \mathrm{~m}\end{array}$ & $\begin{array}{l}\text { NW Spain } \\
598-610 \mathrm{~m}\end{array}$ \\
\hline Length (mm) & 4 & 2.4 & 7 \\
\hline Middorsal keel & - & + & + \\
\hline Epidermal papillae & + & - & + \\
\hline Posterior atrium & Bilobed & Trilobed & Trilobed \\
\hline \multicolumn{4}{|l|}{ Radula teeth } \\
\hline Distal hook & + & - & + \\
\hline Medial denticles & $6-7$ & - & - \\
\hline Radular sheath & Unpaired & Paired/unpaired & Unpaired \\
\hline $\begin{array}{l}\text { Ducts of the ventrolateral } \\
\text { foregut glandular organs }\end{array}$ & Short & Long & Long \\
\hline Oesophagus & Short & Long & Long \\
\hline Oesophageal glands & - & - & + \\
\hline Anterodorsal midgut caecum & Paired/unpaired & Paired/unpaired & Unpaired \\
\hline Midgut constrictions & + & + & - \\
\hline Abdominal spicules & + & - & - \\
\hline Suprapallial glands & + & $?$ & - \\
\hline Respiratory folds & 10 & - & 15 \\
\hline Pedal fold reaches pallial cavity & - & + & - \\
\hline
\end{tabular}

opens very close to the posterior region of the atrium, whereas in other species, as it is in the case of P. artabra n. sp. and P. manifesta n. sp., the atrium and mouth are functionally separated, but linked by a groove. The clear separation of mouth and atrium is characterized by the fact that between both openings there is a cuticular covering and bundles of circular and retractile musculature above the separation area. In $P$. artabra n. sp. and P. manifesta n. sp. the separation groove between the atrium and the mouth lacks a cuticular coating but shows the typical musculature, whereas in the descriptions of $P$. pallioglandulata and $P$. uniperata, it is pointed out that this groove is weakly cuticularized (Salvini-Plawen 1978). However, the combination of the characters absence of copulatory stylets and presence of serial lateral constrictions on the midgut and respiratory folds on the pallial cavity clearly differentiates the genus Pruvotina from the other two genera of the subfamily Pararrhopaliinae: Pararrhopalia Simroth, 1903 and Labidoherpia Salvini-Plawen 1978 (Table 1). Therefore, we consider that the position of the mouth opening should not be taken into account in the diagnosis of Pruvotina, as it is an ambiguous generic character.

Concerning the genus Gephyroherpia, both species known so far have a midgut with serial lateral constrictions, but $G$. impar n. sp. lacks them (Table 3); therefore, this character should be considered as specific and not as generic.

The two new species of Gephyroherpia and Pruvotina from NW Spain are the first records of both genera in the geographical Atlantic region of Iberian Peninsula. Despite the little information on the distribution of Solenogastres, the available data indicate that many of the genera of the class could have a global distribution, except for some that would be limited to a kind of typical habitat, such as abyssal bottoms or hydrothermal vents (Scheltema and Kuzirian 1991; Scheltema 2000; Salvini-Plawen 2008b). Nevertheless, it is necessary to extend the studies to other geographical areas and bathymetries to get to know the reality about the biodiversity and distribution of Solenogastres.

Acknowledgments The authors are very grateful to Prof. Dr. Luitfried Salvini-Plawen (Vienna University) for his help to improve this work. This paper is a contribution to the following projects carried out by the Marine Biological Station of A Graña from the University of Santiago de Compostela: PGIDT01PXI20008PR, PGIDIT05PXIC 20001P, PGIDIT07PXB000120PR, A Selva-08 and ForSaGal-09 (Xunta de Galicia Regional Government); VEM2003-20070-C04-04, CGL2004-22429-E and CTM2004-00740 (MEC, Spanish Government). The paper is also a part of the research project BENTART REN2003-01881/ANT (MEC, Spanish Government). The first author was supported by a scholarship from the FPU Programme (MEC, Spanish Government).

\section{References}

García-Álvarez O, Salvini-Plawen LV (2007) Species and diagnosis of the families and genera of Solenogastres (Mollusca). Iberus 25(2):73-143 
García-Álvarez O, Urgorri V (2001) Luitfriedia minuta gen. et sp. nov. (Mollusca: Solenogastres), a new species from Galicia, North-West Spain. Cah Biol Mar 42(3):197-202

García-Álvarez O, LV Salvini-Plawen, Urgorri V (2001) Unciherpia hirsuta a new genus and species of Aplacophora (Mollusca Solenogastres: Pararrhopaliidae) from Galicia, Northwest Spain. J Moll Stud 67:113-119

García-Álvarez O, Zamarro M, Urgorri V (2009) Proneomeniidae (Solenogastres, Cavibelonia) from the Bentart-2006 Expedition, with description of a new species. Iberus 27(1):67-78

Gil-Mansilla E, García-Álvarez O, Urgorri V (2011) A new genus and two new species of Cavibelonia (Mollusca: Solenogastres) from the Abyssal Angola Basin. Cah Biol Mar 52(2):233-243

Handl C, Todt C (2005) Foregut glands of Solenogastres (Mollusca): anatomy and revised terminology. J Morphol 265(1):28-42

Heath H (1911) Reports on the scientific results of the expedition to the tropical Pacific, XIV. The Solenogastres. Mem Mus Comp Zool Harvard Coll 45(1):1-182

Heath H (1918) Solenogastres from the Eastren Coast of North America. Mem Mus Comp Zool Harvard Coll 45(2):183-263

Pelseneer P (1901) Les Néoméniens de l'Expédition antarctique belge et la distribution géographique des Aplacophora. Bull Acad R Sci Lett B-Arts Belg 9-10:528-534

Pelseneer P (1903) Zoologie: Mollusques (Amphineures, Gastropodes et Lamellibranches). Résultats Voyage S. Y. Belgica (1897-1899) sous le commandement de A. Gerlache de Gomery: Rapports Scient. (1901-1913). Buschmann, Anvers, Belgium

Pruvot G (1890) Sur quelques Néoméniées nouvelles de la Méditerranée. Arch Zool Exp Gén Sér 2(8):21-24

Pruvot G (1891) Sur l'organisation de quelques Néoméniens des côtes de France. Arch Zool Exp Gén Sér 2(9):699-810

Pruvot G (1897) Essai sur les fonds et la faune de la Manche Occidentale (Cotes de Bretagne) comparés a ceux du Golfe du Lion. Arch Zool Exp Gén Sér 3(5):511-660
Salvini-Plawen LV (1978) Antarktische und subantarktische Solenogastres (Eine Monographie: 1898-1974). Zoologica (Stuttgart) 128:1-315

Salvini-Plawen LV (1997) Fragmented knowledge on West-European and Iberian Caudofoveata and Solenogastres. Iberus 15(2):35-50

Salvini-Plawen LV (2003) Contributions to West-Mediterranean Solenogastres (Mollusca) with three new species. Iberus 21(2):37-60

Salvini-Plawen LV (2008a) Contributions to West European Cavibelonia (Mollusca, Solenogastres) with two new species. Zoosystema 30(4):873-897

Salvini-Plawen LV (2008b) Three new species of Simrothiellidae (Solenogastres) associated with the hot-vent biotope. J Moll Stud 74(3):223-238. doi:10.1093/mollus/eyn010

Salvini-Plawen LV (2009) Two immature pruvotinids from the Irish Sea (Mollusca: Solenogastres). Mar Biod Rec 2:e164. doi: $10.1017 / \mathrm{s} 1755267209990935$

Scheltema AH (2000) Two new hydrothermal vent species, Helicoradomenia bisquama and Helicoradomenia acredema, from the eastern Pacific Ocean (Mollusca, Aplacophora). Argonauta 14(2): $15-25$

Scheltema AH, Kuzirian AM (1991) Helicoradomenia juani gen. et sp. nov., a Pacific hydrothermal vent Aplacophora (Mollusca: Neomeniomorpha). Veliger 34(2):195-203

Thiele J (1902) Proneomenia valdiviae n. sp. Wissusch Ergednisse Dtsch Tiefsee-Exped Valdivia, 1898-1899 3:167-174

Thiele J (1913) Antarktische Solenogastren. Dtsch Südpolar-Exp 1901-1903 14, Zool, Heft 6(1): 35-65

Todt C (2006) Ultrastructure of multicellular foregut glands in selected Solenogastres (Mollusca). Zoomorphology 125(3): 119-134. doi:10.1007/s00435-006-0016-y 